\title{
\#USGS
}

Prepared in cooperation with the Bureau of Reclamation

Status and Trends of Adult Lost River (Deltistes luxatus) and Shortnose (Chasmistes brevirostris) Sucker Populations in Upper Klamath Lake, Oregon, 2015 
Cover: Photograph showing U.S. Geological Survey scientist measuring, tagging, and releasing an endangered Lost River sucker on the eastern shoreline of Upper Klamath Lake, Oregon, April 13, 2015. Photograph by Brian Hayes, U.S. Geological Survey. 


\section{Status and Trends of Adult Lost River (Deltistes luxatus) and Shortnose (Chasmistes brevirostris) Sucker Populations in Upper Klamath Lake, Oregon, 2015}

By David A. Hewitt, Eric C. Janney, Brian S. Hayes, and Alta C. Harris

Prepared in cooperation with the Bureau of Reclamation

Open-File Report 2017-1059

U.S. Department of the Interior

U.S. Geological Survey 


\section{U.S. Department of the Interior \\ RYAN K. ZINKE, Secretary}

\section{U.S. Geological Survey \\ William H. Werkheiser, Acting Director}

U.S. Geological Survey, Reston, Virginia: 2017

For more information on the USGS-the Federal source for science about the Earth, its natural and living resources, natural hazards, and the environment-visit https://www.usgs.gov/ or call 1-888-ASK-USGS (1-888-275-8747).

For an overview of USGS information products, including maps, imagery, and publications, visit https:/store.usgs.gov.

Any use of trade, firm, or product names is for descriptive purposes only and does not imply endorsement by the U.S. Government.

Although this information product, for the most part, is in the public domain, it also may contain copyrighted materials as noted in the text. Permission to reproduce copyrighted items must be secured from the copyright owner.

Suggested citation:

Hewitt, D.A., Janney, E.C., Hayes, B.S., and Harris, A.C., 2017, Status and trends of adult Lost River (Deltistes luxatus) and shortnose (Chasmistes brevirostris) sucker populations in Upper Klamath Lake, Oregon, 2015: U.S. Geological Survey Open-File Report 2017-1059, 38 p., https://doi.org/10.3133/ofr20171059.

ISSN 2331-1258 (online) 


\section{Contents}

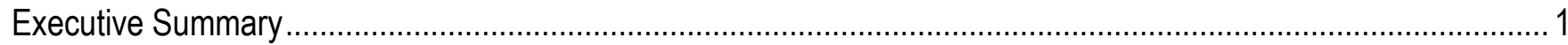

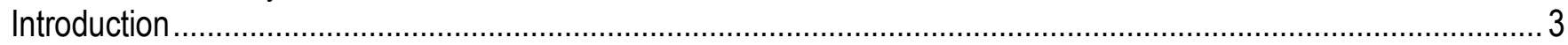

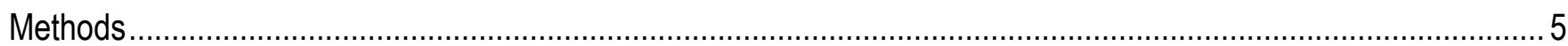

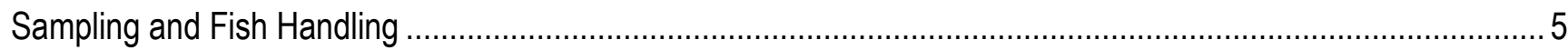

Remote Passive Integrated Transponder Tag Detection Systems ............................................................ 6

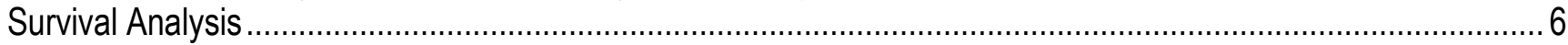

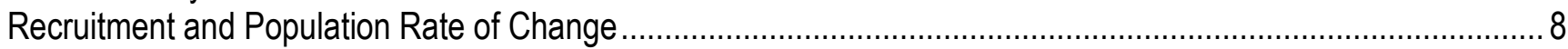

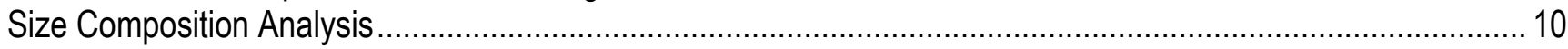

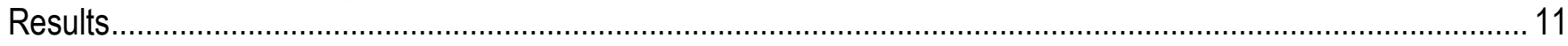

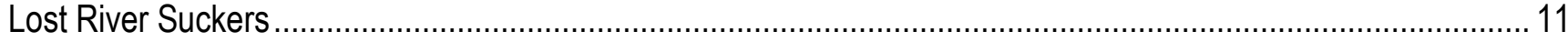

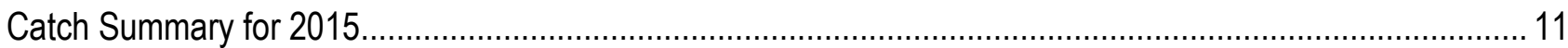

Survival, Recruitment, and Size Composition....................................................................................... 13

Upper Klamath Lake Lakeshore Spawning Subpopulation .............................................................. 13

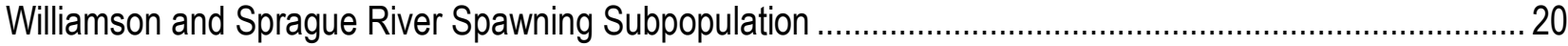

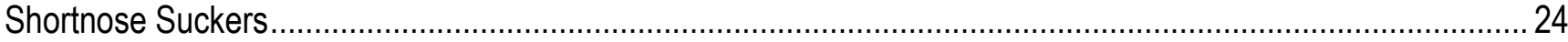

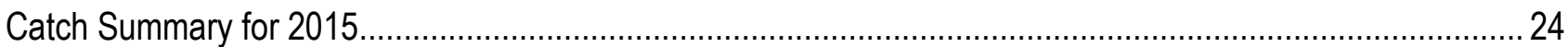

Survival, Recruitment, and Size Composition................................................................................ 24

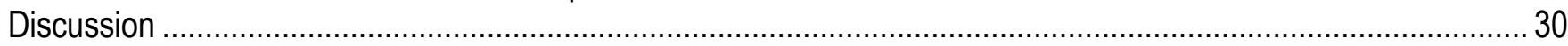

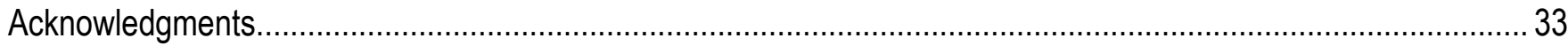

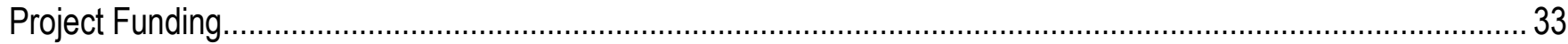

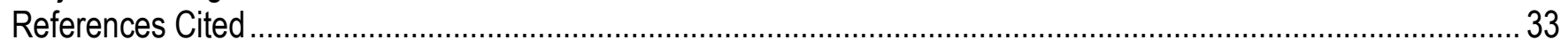

\section{Figures}

Figure 1. Map showing sampling locations for Lost River suckers and shortnose suckers in Upper Klamath Lake and its tributaries, Oregon .............................................................................. 4

Figure 2. Graph showing realized proportional change in the size of the lakeshore spawning subpopulation of Lost River suckers from 2001 to 2014

Figure 3. Boxplots showing fork lengths of male and female Lost River suckers captured in trammel nets at lakeshore springs, 1999-2015.

Figure 4. Boxplots of fork lengths of male and female Lost River suckers captured at pre-spawn staging areas in Upper Klamath Lake and in the Williamson and Sprague Rivers, 2000-2015

Figure 5. Graph showing realized proportional change in the size of the shortnose sucker spawning population from 2001 to 2014.

Figure 6. Boxplots showing fork lengths of male and female shortnose suckers captured in Upper Klamath Lake and the Williamson and Sprague Rivers, 1995-2015. 


\section{Tables}

Table 1 Numbers of Lost River suckers and shortnose suckers captured in Upper Klamath Lake (UKL) and the Williamson River, Oregon, 2003-15.

Table 2. Numbers of Lost River suckers and shortnose suckers detected by remote passive integrated transponder tag antennas in Upper Klamath Lake (UKL) and its tributaries, Oregon, 2015.

Table 3. Model selection results for the Cormack-Jolly-Seber capture-recapture models fitted to the data for adult Lost River sucker and shortnose sucker populations in Upper Klamath Lake, Oregon.

Table 4. Demographic parameter estimates for Lost River suckers from the lakeshore spawning subpopulation, Upper Klamath Lake, Oregon....

Table 5. Model selection results for the reverse time Cormack-Jolly-Seber (seniority) capture-recapture models fitted to the data for adult sucker populations in Upper Klamath Lake, Oregon.

Table 6. Demographic parameter estimates for Lost River suckers from the river spawning subpopulation, Upper Klamath Lake, Oregon.

Table 7. Demographic parameter estimates for the shortnose sucker spawning population, Upper Klamath Lake, Oregon.

\section{Conversion Factors}

International System of Units to Inch/Pound

\begin{tabular}{lll}
\hline \multicolumn{1}{c}{ Multiply } & \multicolumn{1}{c}{ By } & To obtain \\
\hline centimeter $(\mathrm{cm})$ & \multicolumn{1}{c}{ Length } & \\
millimeter $(\mathrm{mm})$ & 0.3937 & inch (in.) \\
meter $(\mathrm{m})$ & 0.03937 & inch (in.) \\
kilometer $(\mathrm{km})$ & 3.281 & foot (ft) \\
\hline
\end{tabular}

Temperature in degrees Celsius $\left({ }^{\circ} \mathrm{C}\right)$ may be converted to degrees Fahrenheit $\left({ }^{\circ} \mathrm{F}\right)$ as: ${ }^{\circ} \mathrm{F}=\left(1.8 \times{ }^{\circ} \mathrm{C}\right)+32$.

\section{Acronyms}

$\begin{array}{ll}\text { CJS } & \text { Cormack-Jolly-Seber } \\ \text { FL } & \text { fork length } \\ \text { LRS } & \text { Lost River sucker } \\ \text { PIT } & \text { passive integrated transponder } \\ \text { SNS } & \text { shortnose sucker } \\ \text { UKL } & \text { Upper Klamath Lake }\end{array}$




\title{
Status and Trends of Adult Lost River (Deltistes luxatus) and Shortnose (Chasmistes brevirostris) Sucker Populations in Upper Klamath Lake, Oregon, 2015
}

\author{
By David A. Hewitt, Eric C. Janney, Brian S. Hayes, and Alta C. Harris
}

\section{Executive Summary}

Data from a long-term capture-recapture program were used to assess the status and dynamics of populations of two long-lived, federally endangered catostomids in Upper Klamath Lake, Oregon. Lost River suckers (LRS; Deltistes luxatus) and shortnose suckers (SNS; Chasmistes brevirostris) have been captured and tagged with passive integrated transponder (PIT) tags during their spawning migrations in each year since 1995. In addition, beginning in 2005, individuals that had been previously PIT-tagged were re-encountered on remote underwater antennas deployed throughout sucker spawning areas. Captures and remote encounters during the spawning season in spring 2015 were incorporated into capture-recapture analyses of population dynamics.

Cormack-Jolly-Seber (CJS) open population capture-recapture models were used to estimate annual survival probabilities, and a reverse-time analog of the CJS model was used to estimate recruitment of new individuals into the spawning populations. In addition, data on the size composition of captured fish were examined to provide corroborating evidence of recruitment. Model estimates of survival and recruitment were used to derive estimates of changes in population size over time and to determine the status of the populations through 2014. Separate analyses were done for each species and also for each subpopulation of LRS. Shortnose suckers and one subpopulation of LRS migrate into tributary rivers to spawn, whereas the other LRS subpopulation spawns at groundwater upwelling areas along the eastern shoreline of the lake.

In 2015, we captured, tagged, and released 413 LRS at four lakeshore spawning areas and recaptured an additional 1,041 individuals that had been tagged in previous years. Across all four areas, the remote antennas detected 6,301 individual LRS during the spawning season. Spawning activity peaked in late March and April, and most individuals were encountered at Cinder Flats and Sucker Springs. In the Williamson River, we captured, tagged, and released 2,601 LRS and 215 SNS, and recaptured 704 LRS and 123 SNS that had been tagged in previous years. Remote PIT tag antennas in the traps at the weir on the Williamson River and remote antenna systems that spanned the river at three different locations on the Williamson and Sprague Rivers detected a total of 25,173 LRS and 6,459 SNS. Most LRS passed upstream in late March and early April, when water temperatures were increasing and greater than $10^{\circ} \mathrm{C}$. In contrast, upstream passage for SNS occurred in three pulses, one in late March, one in mid-April, and one in late April to early May, when water temperatures were increasing and near or greater than $12{ }^{\circ} \mathrm{C}$. Finally, an additional 590 LRS and 2,114 SNS were captured in trammel net sampling at pre-spawn staging areas in the northeastern part of the lake. Of these, 190 of the LRS and 919 of the SNS had been PIT-tagged in previous years. For LRS captured at the staging areas that had encounter histories that were informative about their spawning location, 86 percent of the fish were members of the subpopulation that spawns in the rivers. 
Capture-recapture analyses for the LRS subpopulation that spawns at the shoreline areas included encounter histories for 13,617 individuals, and analyses for the subpopulation that spawns in the rivers included 39,321 encounter histories. With a few exceptions, the survival of males and females in both subpopulations was high $(\geq 0.86)$ between 1999 and 2013. Survival was notably lower for males from the rivers in 2000, 2006, and 2012. Survival probabilities were lower for males from the shoreline areas in 2002. Between 2001 and 2014, the abundance of males in the lakeshore spawning subpopulation decreased by at least 59 percent and the abundance of females decreased by at least 53 percent. Capture-recapture models suggested that the abundance of both sexes in the river spawning subpopulation of LRS had increased substantially since 2006; increases were mostly due to large estimated recruitment events in 2006 and 2008. We know that the estimates in 2006 are substantially biased in favor of recruitment because of a sampling issue. We are skeptical of the magnitude of recruitment indicated by the 2008 estimates as well because (1) few small individuals that would indicate the presence of new recruits were captured in that year, and (2) recapture probabilities in recruitment models based on just physical recaptures of fish were lower than desired for robust inferences from capture-recapture models. If we assume instead that little or no recruitment occurred for this subpopulation, the abundance of both sexes in the river spawning subpopulation likely has decreased at rates similar to the rates for the lakeshore spawning subpopulation between 2002 and 2014.

Capture-recapture analyses for SNS included encounter histories for 20,981 individuals. Most annual survival estimates between 2005 and 2009 were high (greater than 0.88), but both sexes of SNS experienced lower and more variable survival in 2001-04 and 2010-13. Capture-recapture models and size composition data indicate that recruitment of new individuals into the SNS spawning population was trivial between 2001 and 2005. Models indicate that 10 percent or more of the population was new recruits in a number of more recent years. As a result, capture-recapture modeling suggests that the abundance of adult spawning SNS was relatively stable between 2006 and 2010. We are skeptical of the estimated recruitment in 2006 because of the known sampling issue. We also are skeptical of the estimated recruitment in other recent years because few small individuals that would indicate the presence of new recruits were captured in any of those years, and recapture probabilities in recruitment models were low. The best-case scenario for SNS, based on capture-recapture recruitment modeling, indicates that the abundance of males in the spawning population decreased by 77 percent and the abundance of females decreased by 74 percent between 2001 and 2014. Decreases in abundance for both sexes likely are greater than these estimates indicate.

Despite relatively high survival in most years, we conclude that both species have experienced substantial decreases in the abundance of spawning adults because losses from mortality have not been balanced by recruitment of new individuals. Although capture-recapture data indicate substantial recruitment of new individuals into the spawning populations for SNS and river spawning LRS in some years, size data do not corroborate these estimates. As a result, the status of the endangered sucker populations in Upper Klamath Lake remains worrisome, especially for SNS. Our monitoring program provides a robust platform for estimating vital population parameters, evaluating the status of the populations, and assessing the effectiveness of conservation and recovery efforts. 


\section{Introduction}

Lost River suckers (LRS; Deltistes luxatus) and shortnose suckers (SNS; Chasmistes brevirostris) are long-lived catostomids that are endemic to the Upper Klamath River Basin in southern Oregon and northern California (Scoppettone and Vinyard, 1991). Historical accounts indicate that both species once were extremely abundant throughout the upper basin and were caught in a subsistence fishery by Native Americans and later in a popular recreational snag fishery that was closed in 1987 (Markle and Cooperman, 2002). Decreasing population abundance trends and range reductions were noted for both species as early as the mid-1960s. However, the extent of these declines was not evident until the mid-1980s when recreational catch rates showed substantial decreases that were partly attributed to overfishing (Markle and Cooperman, 2002; National Research Council, 2004). Estimated annual fishery harvest of spawning suckers in the Williamson and Sprague Rivers, tributaries to Upper Klamath Lake in Oregon, decreased from more than 10,000 fish in 1968 to 687 fish in 1985 (Markle and Cooperman, 2002). In addition to decreasing catches, age data from suckers collected during a 1986 fish die-off indicated that the LRS population was composed of old individuals and that no substantial recruitment had occurred during the previous 15 years (Scoppettone and Vinyard, 1991; U.S. Fish and Wildlife Service, 1993). These findings led to the Federal listing of both species under the Endangered Species Act in 1988 (U.S. Fish and Wildlife Service, 1988). Upper Klamath Lake contains the largest remaining population of LRS (National Research Council, 2004) and one of the largest remaining populations of SNS.

Life history and spawning characteristics of suckers in Upper Klamath Lake are reasonably well documented (Scoppettone and Vinyard, 1991; Moyle, 2002; Cooperman and Markle, 2003). Age estimates for LRS have exceeded 50 years, and age estimates for SNS have exceeded 30 years (National Research Council, 2004; Terwilliger and others, 2010). Both species are obligate lake dwellers that make spawning migrations between March and May of each year. Shortnose suckers spawn primarily in the Williamson and Sprague Rivers, but two distinct subpopulations of LRS have been identified in Upper Klamath Lake (National Research Council, 2004). One subpopulation spawns in the Williamson and Sprague Rivers, and the other subpopulation spawns at several groundwater upwelling areas (referred to as springs) along the eastern shoreline of the lake below Modoc Rim (fig. 1). Capturerecapture data show an extremely high degree of spawning site fidelity and little reproductive mixing between the two subpopulations (Janney and others, 2008; Hewitt and others, 2012). 


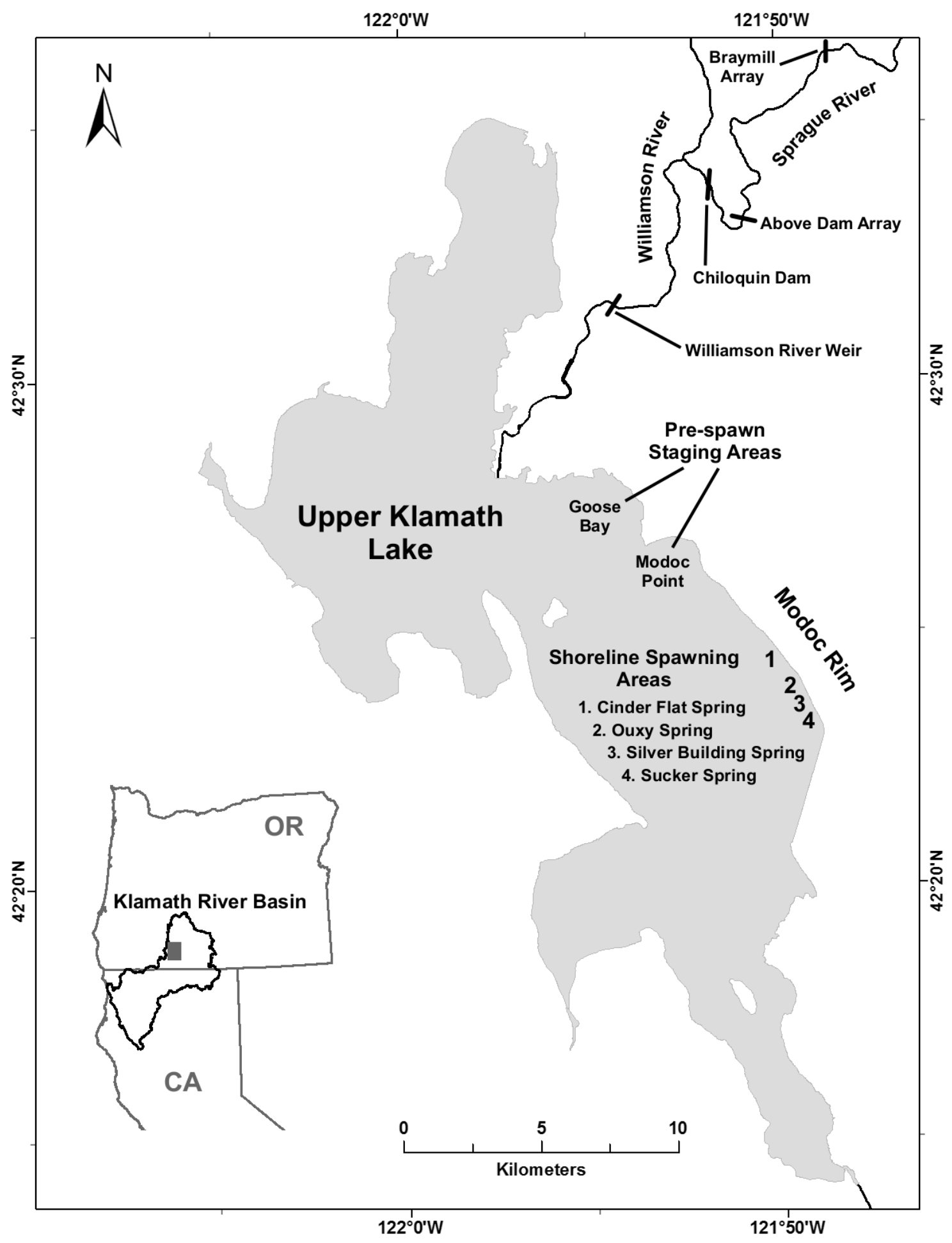

Figure 1. Map showing sampling locations for Lost River suckers and shortnose suckers in Upper Klamath Lake and its tributaries, Oregon. The inset shows the Klamath River Basin and the location of Upper Klamath Lake in south-central Oregon. 
Although fishing mortality was eliminated with the closure of the recreational fishery in 1987, poor survival of adult suckers is still considered a factor that can potentially limit recovery of Upper Klamath Lake populations (Janney and others, 2008). Upper Klamath Lake is a large, shallow system that has progressed to a hypereutrophic state because of increased nutrient loading from wetland drainage, grazing, and timber harvest (Bradbury and others, 2004; Eilers and others, 2004). These conditions lead to massive blooms of the cyanobacterium Aphanizomenon flos-aquae between June and October of each year (Wood and others, 2006; Hoilman and others, 2008; Lindenberg and others, 2009; Eldridge and others, 2012). The algal blooms and their subsequent die-offs produce water quality conditions that are harmful to fish health-low concentrations of dissolved oxygen, elevated concentrations of ammonia, high $\mathrm{pH}$, and high concentrations of toxic microcystins (Kann and Smith, 1999; Eldridge and others, 2013). Poor water quality conditions are thought to have contributed to a number of substantial fish die-offs in the lake, most recently during the summers of 1986, 1995, 1996, and 1997 (Perkins and others, 2000; National Research Council, 2004), and to a much lesser extent in 2003 (U.S. Geological Survey, unpub. data, 2003).

In this report, we analyze capture-recapture data from 1999 to 2015 to evaluate demographic trends in LRS and SNS spawning populations. Annual adult survival and recruitment probabilities were modeled and compared to assess differences attributable to species, LRS subpopulation, sex, and year. We used model-averaged estimates of these probabilities to calculate estimates of population rate of change and to determine status as of spring 2014. In addition to estimating recruitment from capturerecapture data, we assessed relative changes in size composition to provide additional insight into the frequency and magnitude of recruitment into the spawning populations.

\section{Methods}

\section{Sampling and Fish Handling}

Lost River suckers from the subpopulation that spawns at springs along the eastern shoreline of Upper Klamath Lake were sampled at four locations (fig. 1) using 30-m trammel nets ( $1.8 \mathrm{~m}$ high; two 30 -cm mesh outer panels; one $3.8-\mathrm{cm}$ mesh inner panel; foam-core float line; lead-core bottom line). Nets generally were set twice per week at each spawning area between February and May from 1999 to 2015. The only exception to this sampling schedule occurred in 2006, when each spawning area was sampled only once per week. Nets were set starting at the shoreline and extending out in a semicircular fashion, encompassing the area where spawning activity was concentrated.

Lost River and shortnose suckers also were sampled at two locations in tributary rivers. Between 2000 and 2008, fish were sampled three times per week at the Chiloquin Dam fish ladder on the Sprague River (fig. 1). Before sampling, a screen was placed over the bottom entrance (outflow) to prevent fish from exiting, and the upstream end (inflow) was blocked by a board to lower the water level in the cells of the fish ladder. A combination of dip nets and short trammel nets was used to collect fish trapped in the ladder. Chiloquin Dam and the associated fish ladder were removed from the river in the late summer and autumn of 2008. Beginning in 2005 and continuing through 2015, a resistance board weir (described in detail by Tobin, 1994) was installed on the Williamson River at river kilometer 10 to improve capture rates of suckers during the spawning migrations (fig. 1). The weir restricted the passage of suckers to two short sections, each fitted with a live trap. An upstream trap was used to capture fish as they migrated upriver, and a downstream trap was left open to allow downriver migrating suckers to pass the weir. High flows in the Williamson River during most of the 2006 spawning season inundated the weir and allowed fish to pass over and around the weir without swimming through the upstream trap. 
Additional trammel net sampling for pre-spawn adult suckers of both species was conducted from 1995 to 2015 at various staging areas in Upper Klamath Lake. Most of this sampling, especially after 2005, has taken place near Modoc Point and Goose Bay (fig. 1). Between 1995 and 2006, prespawn suckers were sampled with trammel nets in the lowest $2 \mathrm{~km}$ of the Williamson River (Janney and others, 2006).

Suckers captured at all sample locations were identified to species and sex, measured for fork length (FL), and scanned for the presence of a passive integrated transponder (PIT) tag. If a PIT tag was not detected, one was inserted into the ventral abdominal musculature anterior to the pelvic girdle. From 1995 to 2004, suckers were tagged with $125 \mathrm{kHz}$ full-duplex PIT tags. All subsequent tagging, beginning with the 2005 sampling season, has used $134.2 \mathrm{kHz}$ full-duplex tags.

\section{Remote Passive Integrated Transponder Tag Detection Systems}

In addition to capture sampling, detections of PIT-tagged fish on remote antennas were incorporated into the capture-recapture study design beginning in 2005. Remote antennas were incorporated to improve the probability of re-encountering previously tagged suckers (Hewitt and others, 2010). Suckers detected by these systems were not physically handled, but were confirmed to be alive and thus were considered live re-encounters in survival analyses. Locations of remote PIT tag detection systems are shown in figure 1 and are listed here with the range of years during which they were operational:

- Antennas on the substrate at lakeshore springs in Upper Klamath Lake (limited in 2005, full implementation in 2006-15);

- One antenna in each of the upstream and downstream traps of the Williamson River weir (2005-15);

- A river-wide antenna array on the substrate immediately upstream of the weir (2007-15);

- A river-wide antenna array on the substrate immediately downstream of the Chiloquin Dam site (2008-15);

- Antennas in the entrance, middle, and exit of the Chiloquin Dam fish ladder (2006-08);

- A river-wide antenna array on the substrate about 2.5 river kilometers upstream of the Chiloquin Dam site (2007-15); and

- A river-wide antenna array on the substrate about 12 river kilometers upstream of the Chiloquin Dam site at Braymill (2009-13).

\section{Survival Analysis}

We used Cormack-Jolly-Seber (CJS) live-recapture models (Williams and others, 2002; Nichols, $2005)$ to obtain maximum likelihood estimates of apparent survival $(\Phi)$ and re-encounter $(p)$ probabilities. Apparent survival includes permanent emigration when the study area is not geographically closed (Pollock and others, 2007). Emigration from Upper Klamath Lake is possible, but radio telemetry indicated that emigration by adults of either sucker species is rare (Reiser and others, 2001; Banish and others, 2009). Similarly, detections of PIT-tagged suckers on remote antennas in the lower Link River (southern outlet of the lake) and the fish ladder at Link River Dam, as well as captures of PIT-tagged suckers in Bureau of Reclamation trammel net sampling in Lake Ewauna (downstream of the Link River), have recorded fewer than 25 suckers emigrating from Upper Klamath Lake by way of the Link River. Therefore, we expect that our estimates of apparent survival are nearly equivalent to true survival. Lost River sucker data were analyzed separately for the two spawning subpopulationslakeshore spawners and river spawners. 
The CJS model makes the following assumptions: (1) tags are not lost or overlooked when individuals are re-encountered; (2) sampling periods are "instantaneous" relative to the interval between sampling periods; and (3) there is no unmodeled individual variability (heterogeneity) in survival or reencounter probabilities among the tagged individuals. Although double-tagging experiments with Floy and PIT tags showed that PIT tag loss rates were less than 1 percent over 3 or more years (U.S. Geological Survey, unpub. data, 2010), an unknown proportion of the $125 \mathrm{kHz}$ PIT tags released in 2001-03 are not detectable on the remote antennas. For fish that were physically recaptured, we ensured that tags were not missed when present by scanning a test tag prior to scanning each fish, and also scanning a test tag after each fish that was found to be untagged. Regarding assumption 2, sampling in our study occurred over a 3-3.5 month spawning period and was not instantaneous. However, most captures and encounters occurred over a much shorter time period, and individuals were fairly consistent from year to year in the relative times at which they joined the spawning aggregations (Burdick and others, 2015). Thus, on an individual basis, sampling can be considered nearly instantaneous relative to an annual interval used for parameter estimation. In addition, spawning fish almost always appeared to be in excellent condition, and water quality was good during the spring. Thus, we expect that mortality during the sampling period was low and did not bias survival estimates.

We assessed whether our data conformed to the assumptions of the CJS model using goodnessof-fit testing in the program U-CARE (Choquet and others, 2009). Goodness-of-fit tests pooled over time indicated significant departures from frequencies expected under the CJS model for LRS subpopulations and for SNS. Lack of fit can be an indication of model assumption violations, sparse data, or lack of independence. Closer examination of our goodness-of-fit tests for individual time periods revealed no consistent or systematic bias that would suggest tagging effects. We suspect that lack of fit was largely due to lack of independence in the encounter histories of tagged fish. The lack of independence, or overdispersion, probably results from schooling behavior and is relatively common in capture-recapture studies of fish (Pollock and others, 2007). An overdispersion correction factor ( $\hat{c}$ ) was determined from the most general model for each species or subpopulation by use of the median $\hat{\mathrm{c}}$ estimation method in program MARK (Cooch and White, 2013). These $\hat{c}$ values were applied to the respective set of candidate models to compensate for overdispersion in model selection statistics and to inflate variances associated with parameter estimates. Applying a variance inflation factor is recommended when heterogeneity is detected in the data and supports a conservative approach to inference based on model selection (Anderson and others, 1994). 
Model sets were developed by considering the effects of sex and time (year) on $\Phi$ and $p$, and then including models with and without those factors. We modeled $\Phi$ as a function of sex because past analyses have shown that female suckers often have higher survival than males (Janney and others, 2008; Hewitt and others, 2012). Most importantly, we modeled $\Phi$ as a function of time to detect changes in annual survival. For $p$, we expected sex to be important because of differences in reproductive behavior; for example, males stay at spawning areas longer than females, potentially increasing their probability of being encountered (Burdick and others, 2015). We also expected time to be important for $p$ because of annual differences in sampling intensity and environmental effects on the condition of spawning habitats. Past analyses showed that models with some combination of both sex and time effects on $p$ were overwhelmingly supported in model selection, so we only considered models with some combination of both effects (Janney and others, 2009; Hewitt and others, 2012). We included models with both additive and interactive effects for $\Phi$ and $p$. Additive models constrained effects to be the same between groups across time (for example, the difference between male and female survival is the same in each year), whereas interactive models included more parameters and allowed effects to vary through time (for example, separate estimates of survival for each sex in each year). Note that, as in many CJS designs, the last estimates of $\Phi$ and $p$ are confounded in the likelihood and cannot be separately estimated. As such, we do not report or discuss estimates of $\Phi$ for 2014 or $p$ for 2015 .

The models used in the analyses were specified and passed to program MARK (White and Burnham, 1999) using the RMark package (Laake, 2011; Laake and Rexstad, 2013) in the R software environment (R Development Core Team, 2011). All model likelihoods were constructed using a logit link function and optimized using the default Newton-Raphson algorithm. We used Akaike's information criterion corrected for small sample bias and adjusted for overdispersion (quasilikelihood AICc, or QAICc) as a statistical criterion to evaluate the competing models (Burnham and Anderson, 2002). Akaike weights $\left(w_{i}\right)$ are reported as a measure of the relative weight among the models, or the likelihood of each model being the best model in the set given the data. Rather than making inferences from only the best model in the set, parameter estimates were model-averaged using the $w_{i}$ as weights. Model-averaged parameter estimates account for model selection uncertainty in the estimated precision of the parameters and thus produce unconditional estimates of variances and standard errors (Buckland and others, 1997).

\section{Recruitment and Population Rate of Change}

A primary requirement for recovering the endangered sucker populations is knowledge of changes in population size over time (U.S. Fish and Wildlife Service, 2012). In addition to survival, recruitment can be estimated from open population capture-recapture data (Pradel, 1996; Franklin, 2001; Nichols, 2005). Specifically, the reverse-time analog of survival can be estimated; this parameter is termed seniority and denoted $\gamma$. Seniority is defined as the probability that an animal present in the sampled population at period $i$ also was present in period $i-1$ (that is, no recruitment when seniority is 1.0). Given estimates of $\Phi$ and $\gamma$, population rate of change $\left(\lambda_{i}=N_{i+1} / N_{i}\right)$ can be estimated without estimating $N$ using the equation:

$$
\lambda_{i}=\frac{\phi_{i}}{\gamma_{i+1}} .
$$


Pradel (1996) introduced a likelihood that models the entire encounter history and is based on the temporal symmetry of capture-recapture data (Nichols and Hines, 2002). This approach combines probabilities describing forward time (survival) and reverse-time (seniority) processes, allowing the direct estimation and modeling of $\lambda$. The assumptions of the temporal symmetry model are similar to assumptions of the Cormack-Jolly-Seber model, but temporal symmetry further assumes that the study area is well defined and does not expand over time and that there is no permanent trap response in encounter probability. The incorporation of remote PIT tag detection systems into our study design in 2005 created a situation in which previously tagged fish have a much greater probability of being reencountered than untagged fish have of being captured in trammel nets. In essence, the remote antenna systems create a dramatic "trap-happy" response in encounter probability (Otis and others, 1978). This difference in encounter probabilities does not cause bias in survival estimates from CJS models, but it does cause substantial bias in estimates of seniority and population rate of change from temporal symmetry models (Franklin, 2001; Hines and Nichols, 2002; Pradel and others, 2010). To avoid such bias, we obtained estimates of survival and seniority from separate model sets and then used the estimates to derive $\lambda$ using equation 1. Early estimates of $\gamma$ are not reported because of poor precision owing to sparse data and because simulations have shown that the initial two $\gamma$ estimates are likely to be substantially more biased than subsequent estimates (Hines and Nichols, 2002).

Encounter histories used to model survival included physical captures and remote detections, but seniority models included only physical captures. Model sets for the seniority analyses were developed and evaluated in a way similar to the survival analyses; however, effects of tag type on $p$ were not included in models for seniority because remote detections were not included. Past seniority analyses for SNS and both subpopulations of LRS have yielded a large number of seniority parameter estimates from time-dependent models on the boundary of 1.0 (Hewitt and others, 2012, 2014). In an attempt to obtain seniority estimates and standard errors that could be used to derive an estimate of $\lambda$ in those years, and to help determine whether estimability issues were the result of sparse recapture data or simply the lack of any measurable recruitment, all time-dependent models constrained $\gamma$ to be the same in years in which $\gamma$ was estimated on the boundary in an unconstrained time-dependent model. As a result, all data for such years contributed to estimation of a single seniority parameter in the model.

Standard errors for the derived estimates of $\lambda$ were calculated using the Delta method. Ideally, estimates of survival and seniority would be generated from a single likelihood using a temporal symmetry model (Pradel, 1996), and the standard error for $\lambda$ estimates would be corrected for the covariance between these two parameters. Our calculation of the standard error of $\lambda$ by the Delta method ignores any covariance between survival and seniority. The effect of this approach on the estimated standard errors is expected to be small, but the presented standard errors for $\lambda$ may be too precise. Derived estimates of $\lambda$ are not reported for years in which both survival and seniority were estimated on the boundary at 1.0. For years in which either survival or seniority was estimated on the boundary (but not both), $\lambda$ was calculated by assuming that the parameter that was estimated on the boundary was equal to 1.0 , and the standard error for $\lambda$ was assumed to be equal to the estimated standard error for the parameter that was not estimated on the boundary. 
Annual estimates of $\lambda$ provide insight into the variability in abundance of adult spawning populations by showing whether the population decreased $(\lambda<1)$, remained stable $(\lambda=1)$, or increased $(\lambda>1)$. We summarize the long-term dynamics of the populations using a quantity known as $\Delta_{t}$, which is simply the cumulative product of the $\lambda$ estimates over a time period of interest (Anthony and others, 2006). This quantity describes the percentage change in population size from the beginning of the period to the end. Values of $\Delta_{t}$ greater than 1.0 (100 percent) indicate increases in population size, and values less than 1.0 indicate decreases in population size. For purposes of calculating $\Delta_{t}, \lambda$ was assumed to be 1.0 in years when both survival and seniority were estimated on the boundary. We emphasize that estimates of $\lambda$ and $\Delta_{t}$ values apply only to the adult spawning populations and are not necessarily representative of changes in the whole populations. Increases in juvenile abundance are not incorporated until those individuals join the spawning aggregations and are fully vulnerable to our sampling. Size composition of the catches in the most recent year may provide an earlier indication of potential recruitment.

\section{Size Composition Analysis}

Fork lengths of captured suckers were used to assess changes in the size structure of the LRS subpopulations and the SNS population over time. This assessment provides additional evidence about recruitment that can be compared with capture-recapture seniority estimates, and also illustrates trends in growth. Length data were grouped separately for each sex in each population or subpopulation. Data from 1999 to 2015 were included for the lakeshore spawning LRS, and data from 2000 to 2015 were included for river spawning LRS and for SNS.

For the lakeshore spawning LRS and for SNS, size composition analyses and capture-recapture analyses are focused on the same statistical populations. In contrast, for the river spawning LRS the two analyses are focused on different statistical populations. To focus only on spawning adults, the capturerecapture analysis is restricted to fish that were encountered in either the Williamson River or the Sprague River during at least one spawning season and that were never encountered at the lakeshore springs. Many LRS are captured during sampling in Upper Klamath Lake outside the spawning areas, and these individuals do not enter our capture-recapture analyses until they are encountered at a spawning area (lakeshore springs or one of the rivers). In contrast, the size composition analysis for the river spawning subpopulation includes all LRS that were never encountered at the lakeshore springs, including fish captured in Upper Klamath Lake that were never encountered at a spawning area. As a result, the size composition analysis may include data for small LRS that are not yet mature but are staging with the spawners in the lake prior to the spawning migration. This is done intentionally to provide an early indication of recruitment to the spawning subpopulation, if and when recruitment occurs. 


\section{Results}

\section{Lost River Suckers}

\section{Catch Summary for 2015}

We captured 1,458 LRS in trammel nets at the lakeshore springs, 1,041 of which had been tagged prior to the 2015 sampling season. The percentage of LRS captured at the springs that were previously tagged increased rather consistently from 23 percent in 2003 to 71 percent in 2015 (table 1). We detected 6,301 PIT-tagged LRS on the remote antennas at the springs; 94 percent of the LRS captured in trammel nets were detected on the remote antennas. Similar to past years, more LRS were captured and detected at Cinder Flats and Sucker Springs than at the other two springs (table 2). The seasonal pattern of captures and detections also was similar to past years, responding to the pattern in water temperature - individuals began accumulating at the spawning areas in late February as water temperatures increased, activity slowed down when water temperatures decreased for a period in late March and early April, and more individuals joined the spawning aggregations in mid-April when water temperatures increased again.

Trammel net sampling at pre-spawn staging areas captured 590 individual LRS (table 1). Of these, 190 had been tagged prior to the 2015 sampling season. The percentage of LRS captured at the staging areas that were previously tagged has increased rather steadily from 4 percent in 2003 to 32 percent in 2015 (table 1). Of the PIT-tagged LRS captured at the staging areas, 86 percent were subsequently captured or detected somewhere in the Williamson or Sprague Rivers, whereas only 6 percent were later captured or detected at the lakeshore springs.

A total of 3,309 LRS were captured in the upstream trap of the Williamson River weir (table 1). Only 704 (21 percent) had been tagged prior to 2015, continuing the long-term trend of a smaller recapture percentage for LRS in the weir compared to the trammel net sampling at the staging areas. The combination of remote PIT tag antennas at the weir (upstream and downstream traps and the riverwide array) detected a total of 25,103 individuals (table 2). A total of 15 individuals that had not been re-encountered since they were captured and tagged in 2001 or before were detected on the remote antennas at the weir in 2015. Two of these fish had not been re-encountered since they were tagged and released in 1996. One of the 17 individuals was also captured in the weir trap; a male that had grown from $588 \mathrm{~mm}$ FL on April 12, 2001 to $653 \mathrm{~mm}$ FL when it was recaptured on April 1, 2015. Similar to past years, the seasonal pattern of the run timing for LRS was responsive to water temperature; most individuals were captured and detected at the weir during the last week of March and the first and second weeks of April when temperatures increased to $10^{\circ} \mathrm{C}$ and higher.

Approximately 9.1 river kilometers upstream of the Williamson River weir, the river-wide antenna array in the Sprague River (just downstream of the old Chiloquin Dam site) detected 5,592 individual LRS (table 2). The most upstream antenna array, located upstream of the Chiloquin Dam site, detected 131 LRS. 
Table 1. Numbers of Lost River suckers and shortnose suckers captured in Upper Klamath Lake (UKL) and the Williamson River, Oregon, 2003-15.

[Totals include only the first capture of an individual at a given location, but individuals may have been captured at more than one location in a year. Recaptures are the percentage of individuals captured in a given year that were implanted with a passive integrated transponder (PIT) tag in a previous year. For captures at UKL Pre-spawn Staging Areas in 2003-06, numbers in parentheses are the number of fish included in the total count for the year that were captured in the Williamson River near its confluence with UKL. Sampling at the Williamson River weir began in 2005. High flows in the river in 2006 inundated the weir and allowed fish to pass over and around the weir without swimming through the trap]

\begin{tabular}{|c|c|c|c|c|c|}
\hline Capture location & Year & Lost River suckers & $\begin{array}{c}\text { Recaptures } \\
\text { (percent) }\end{array}$ & Shortnose suckers & $\begin{array}{c}\text { Recaptures } \\
\text { (percent) }\end{array}$ \\
\hline \multirow[t]{13}{*}{ UKL pre-spawn staging areas } & 2015 & 590 & 32 & 2,114 & 43 \\
\hline & 2014 & 375 & 30 & 884 & 44 \\
\hline & 2013 & 249 & 32 & 1,151 & 43 \\
\hline & 2012 & 1,185 & 25 & 1,664 & 39 \\
\hline & 2011 & 870 & 22 & 1,600 & 36 \\
\hline & 2010 & 1,519 & 17 & 2,952 & 28 \\
\hline & 2009 & 1,533 & 13 & 1,764 & 25 \\
\hline & 2008 & 459 & 12 & 663 & 19 \\
\hline & 2007 & 335 & 8 & 802 & 21 \\
\hline & 2006 & $438(12)$ & 8 & $883(32)$ & 16 \\
\hline & 2005 & $1,037(568)$ & 6 & $1,028(644)$ & 11 \\
\hline & 2004 & $1,141(215)$ & 6 & $1,869(458)$ & 10 \\
\hline & 2003 & $640(237)$ & 4 & $929(343)$ & 9 \\
\hline \multirow[t]{13}{*}{ Williamson River weir } & 2015 & 3,309 & 21 & 338 & 36 \\
\hline & 2014 & 3,800 & 20 & 423 & 37 \\
\hline & 2013 & 3,796 & 13 & 236 & 31 \\
\hline & 2012 & 3,926 & 14 & 422 & 30 \\
\hline & 2011 & 3,126 & 12 & 180 & 32 \\
\hline & 2010 & 3,084 & 9 & 213 & 24 \\
\hline & 2009 & 3,274 & 8 & 367 & 22 \\
\hline & 2008 & 1,313 & 7 & 284 & 21 \\
\hline & 2007 & 2,055 & 6 & 234 & 14 \\
\hline & 2006 & - & - & - & - \\
\hline & 2005 & 816 & 2 & 203 & 13 \\
\hline & 2004 & - & - & - & - \\
\hline & 2003 & - & - & - & - \\
\hline \multirow[t]{13}{*}{ UKL lakeshore springs } & 2015 & 1,458 & 71 & 3 & 67 \\
\hline & 2014 & 1,466 & 66 & 1 & 0 \\
\hline & 2013 & 1,274 & 61 & 4 & 0 \\
\hline & 2012 & 1,718 & 56 & 1 & 0 \\
\hline & 2011 & 1,812 & 56 & 3 & 33 \\
\hline & 2010 & 756 & 50 & 10 & 60 \\
\hline & 2009 & 1,419 & 45 & 7 & 57 \\
\hline & 2008 & 833 & 44 & 3 & 100 \\
\hline & 2007 & 1,212 & 42 & 13 & 69 \\
\hline & 2006 & 579 & 36 & 6 & 83 \\
\hline & 2005 & 1,604 & 34 & 18 & 50 \\
\hline & 2004 & 1,423 & 30 & 29 & 31 \\
\hline & 2003 & 1,762 & 23 & 30 & 37 \\
\hline
\end{tabular}


Table 2. Numbers of Lost River suckers and shortnose suckers detected by remote passive integrated transponder tag antennas in Upper Klamath Lake (UKL) and its tributaries, Oregon, 2015.

[Totals include only the first detection of an individual at a given location, but individuals may have been detected at more than one location]

\begin{tabular}{|c|c|c|c|}
\hline Location of remote antennas & Lost River suckers & Shortnose suckers & Total \\
\hline \multicolumn{4}{|c|}{ Williamson and Sprague Rivers } \\
\hline Williamson River weir & 25,103 & 6,428 & 31,531 \\
\hline Chiloquin Dam array & 5,592 & 533 & 6,125 \\
\hline Upstream of dam array & 131 & 158 & 289 \\
\hline \multicolumn{4}{|c|}{ UKL Lakeshore Springs } \\
\hline Cinder Flats & 4,596 & 44 & 4,640 \\
\hline Ouxy Springs & 2,612 & 16 & 2,628 \\
\hline Silver Building Springs & 3,038 & 8 & 3,046 \\
\hline Sucker Springs & 3,479 & 26 & 3,505 \\
\hline
\end{tabular}

Survival, Recruitment, and Size Composition

Upper Klamath Lake Lakeshore Spawning Subpopulation

From 1999 to 2014, we captured, tagged, and released 5,660 female and 7,368 male LRS at the lakeshore springs. Excluding re-encounters in the year of tagging, we subsequently recaptured or remotely detected 4,933 (87 percent) of the females and 5,762 (78 percent) of the males on at least one occasion through 2015. Fish that were first captured and tagged in 2015 do not contribute to parameter estimation in survival models. However, the subset of those fish that are included in this subpopulation do contribute information to models used in the recruitment analysis ( 254 females and 178 males).

Thirty-five CJS models were fitted to the encounter histories of fish in this subpopulation to estimate apparent annual survival and re-encounter probabilities. The top model in the set accounted for nearly all of the weight in the model set $\left(w_{i}=0.98\right.$; table 3$)$. This model included separate $\Phi$ parameters for each sex in each year, and sex, year, and tag type effects for $p$. Model-averaged estimates of $\Phi$ varied across years and female survival was consistently, albeit only slightly, higher than male survival (table 4). With the exception of males in 2002, survival estimates were within the range expected for animals with a lifespan similar to that of LRS (table 4). Model-averaged estimates of re-encounter probabilities in 2014 were similar to those in 2013, and a complete discussion of the changes in estimates of $p$ over time are reported in Hewitt and others (2015). 
Table 3. Model selection results for the Cormack-Jolly-Seber capture-recapture models fitted to the data for adult Lost River sucker and shortnose sucker populations in Upper Klamath Lake, Oregon.

[Akaike's Information Criterion corrected for small sample size and overdispersion (quasilikelihood AICc [QAICc]) was used to compare the candidate models of survival $(\Phi)$ and re-encounter $(p)$ probabilities. The overdispersion correction factor, $\hat{c}$, is given for each model set. Thirty-five models were fitted to the data from each population, but only plausible models ( $\triangle$ QAICc less than 20$)$ are shown. In the model names, a $\times$ symbol indicates fully interactive effects and the + symbol indicates additive effects. The tagtype effect on $p$ in the model name refers to the difference between $125 \mathrm{kHz}$ and $134.2 \mathrm{kHz}$ PIT tags, which is only included for 2006 through 2015. The tagtype effect is either constrained to be the same across years (tagtype alone) or allowed to vary by year (tagtype $\times$ time). Both structures were combined additively $(+$ precedes tagtype) and interactively ( $\times$ precedes tagtype) with the other effects in the models. The best model in each set is presented first, and $\triangle$ QAICc values are the difference between the QAICc value of a given model and that of the best model. Akaike weights $\left(w_{\mathrm{i}}\right)$ provide a measure of the relative weight of each model or the likelihood of it being the best model in the set given the data. Number of parameters $(K)$ is the total number that is theoretically estimable in the model]

\begin{tabular}{|c|c|c|c|c|c|}
\hline Model & $K$ & QAICC & $\triangle Q$ QAICC & $w_{i}$ & $-2 \log _{\mathrm{e}} L$ \\
\hline \multicolumn{6}{|c|}{ Lakeshore Spawning Lost River Suckers, 1999-2015 ( $\hat{\mathbf{c}}=1.57)$} \\
\hline$\Phi($ sex $\times$ time $) p($ sex $\times$ time $+[$ tagtype $\times$ time $])$ & 72 & $50,062.3$ & 0.0 & 0.98 & $78,371.5$ \\
\hline$\Phi($ sex + time $) p($ sex $\times$ time $+[$ tagtype $\times$ time $])$ & 58 & $50,071.6$ & 9.3 & 0.01 & $78,430.1$ \\
\hline$\Phi($ sex $\times$ time $) p($ sex $\times$ time $\times$ tagtype $)$ & 82 & $50,072.0$ & 9.7 & 0.01 & $78,355.2$ \\
\hline$\Phi($ sex + time $) p($ sex $\times$ time $\times$ tagtype $)$ & 68 & $50,080.9$ & 18.6 & 0.00 & $78,413.3$ \\
\hline \multicolumn{6}{|c|}{ River Spawning Lost River Suckers, 2000-15 $(\hat{\mathbf{c}}=1.38)$} \\
\hline$\Phi($ sex $\times$ time $) p($ sex $\times$ time $\times$ tagtype $)$ & 78 & $124,826.4$ & 0.0 & 1.00 & $172,045.0$ \\
\hline \multicolumn{6}{|l|}{ Shortnose Suckers, 1999-2015 $(\hat{c}=1.21)$} \\
\hline$\Phi($ sex $\times$ time $) p($ sex $\times$ time $+[$ tagtype $\times$ time $])$ & 72 & $82,587.1$ & 0.0 & 1.00 & $99,755.9$ \\
\hline$\Phi($ sex $\times$ time $) p($ sex + time $+[$ tagtype $\times$ time $])$ & 57 & $82,599.8$ & 12.7 & 0.00 & $99,807.6$ \\
\hline$\Phi($ sex $\times$ time $) p($ sex $\times$ time $\times$ tagtype $)$ & 82 & $82,602.6$ & 15.5 & 0.00 & $99,750.4$ \\
\hline
\end{tabular}


Table 4. Demographic parameter estimates for Lost River suckers from the lakeshore spawning subpopulation, Upper Klamath Lake, Oregon.

[Model-averaged estimates of annual apparent survival probabilities $(\Phi)$ and seniority probabilities $(\gamma)$, the derived estimates of annual population rate of change $(\lambda)$, and the estimated standard errors (SE) and 95 percent confidence intervals $(\mathrm{CI})$ for all estimates. Confounded parameters (C) and estimates on the boundary at $1.0(\mathrm{~B})$ are shaded gray]

\begin{tabular}{|c|c|c|c|c|c|c|c|c|c|c|}
\hline Sex & Year & $\Phi$ Est & $\Phi$ SE & $\Phi \mathrm{Cl}$ & $\gamma$ Est & $\gamma \mathrm{SE}$ & $\gamma \mathrm{Cl}$ & $\lambda$ Est & $\lambda \mathrm{SE}$ & $\lambda \mathrm{Cl}$ \\
\hline Female & 1999 & 0.91 & 0.085 & $0.57-0.99$ & $\mathrm{C}$ & NA & NA & NA & NA & NA \\
\hline Female & 2000 & 0.92 & 0.051 & $0.75-0.99$ & NA & NA & NA & NA & NA & NA \\
\hline Female & 2001 & B & NA & NA & 0.99 & 0.006 & $0.98-1.00$ & 1.01 & 0.006 & $1.00-1.02$ \\
\hline Female & 2002 & 0.88 & 0.031 & $0.81-0.93$ & 0.99 & 0.006 & $0.98-1.00$ & 0.89 & 0.032 & $0.83-0.95$ \\
\hline Female & 2003 & 0.90 & 0.027 & $0.83-0.94$ & 0.99 & 0.006 & $0.98-1.00$ & 0.91 & 0.028 & $0.85-0.96$ \\
\hline Female & 2004 & 0.95 & 0.022 & $0.89-0.98$ & 0.99 & 0.006 & $0.98-1.00$ & 0.96 & 0.023 & $0.92-1.01$ \\
\hline Female & 2005 & 0.94 & 0.012 & $0.91-0.96$ & 0.99 & 0.006 & $0.98-1.00$ & 0.95 & 0.014 & $0.92-0.97$ \\
\hline Female & 2006 & 0.96 & 0.006 & $0.95-0.97$ & 0.99 & 0.006 & $0.98-1.00$ & 0.97 & 0.009 & $0.95-0.98$ \\
\hline Female & 2007 & 0.96 & 0.005 & $0.95-0.97$ & 0.99 & 0.006 & $0.98-1.00$ & 0.97 & 0.008 & $0.95-0.98$ \\
\hline Female & 2008 & 0.95 & 0.006 & $0.93-0.96$ & 0.99 & 0.006 & $0.98-1.00$ & 0.96 & 0.008 & $0.94-0.97$ \\
\hline Female & 2009 & 0.95 & 0.006 & $0.94-0.96$ & 0.99 & 0.006 & $0.98-1.00$ & 0.96 & 0.008 & $0.95-0.98$ \\
\hline Female & 2010 & 0.93 & 0.007 & $0.92-0.94$ & 0.99 & 0.006 & $0.98-1.00$ & 0.94 & 0.009 & $0.92-0.96$ \\
\hline Female & 2011 & 0.93 & 0.006 & $0.91-0.94$ & 0.99 & 0.006 & $0.98-1.00$ & 0.93 & 0.009 & $0.92-0.95$ \\
\hline Female & 2012 & 0.91 & 0.007 & 0.89-0.92 & 0.99 & 0.006 & $0.98-1.00$ & 0.92 & 0.009 & \\
\hline Female & 2013 & 0.90 & 0.007 & 0.89-0.92 & 0.99 & 0.006 & $0.98-1.00$ & 0.91 & 0.009 & $0.90-0.93$ \\
\hline Female & 2014 & $\mathrm{C}$ & NA & NA & 0.99 & 0.006 & $0.98-1.00$ & NA & NA & NA \\
\hline Male & 1999 & 0.90 & 0.041 & $0.79-0.95$ & $\mathrm{C}$ & NA & NA & NA & NA & NA \\
\hline Male & 2000 & 0.98 & 0.037 & $0.60-1.00$ & NA & NA & NA & NA & NA & NA \\
\hline Male & 2001 & B & NA & NA & 0.96 & 0.004 & $0.96-0.97$ & 1.04 & 0.041 & $0.96-1.12$ \\
\hline Male & 2002 & 0.80 & 0.030 & $0.73-0.85$ & 0.96 & 0.003 & $0.96-0.97$ & 0.83 & 0.031 & $0.77-0.89$ \\
\hline Male & 2003 & 0.86 & 0.022 & $0.81-0.90$ & 0.96 & 0.003 & $0.96-0.97$ & 0.90 & 0.023 & $0.85-0.94$ \\
\hline Male & 2004 & 0.93 & 0.018 & 0.89-0.96 & 0.96 & 0.003 & $0.96-0.97$ & 0.97 & 0.019 & $0.93-1.00$ \\
\hline Male & 2005 & 0.91 & 0.011 & $0.89-0.93$ & 0.96 & 0.003 & $0.96-0.97$ & 0.95 & 0.012 & $0.92-0.97$ \\
\hline Male & 2006 & 0.89 & 0.007 & $0.88-0.90$ & 0.96 & 0.003 & $0.96-0.97$ & 0.92 & 0.008 & $0.91-0.94$ \\
\hline Male & 2007 & 0.93 & 0.006 & $0.92-0.94$ & 0.96 & 0.003 & $0.96-0.97$ & 0.96 & 0.007 & $0.95-0.98$ \\
\hline Male & 2008 & 0.91 & 0.007 & $0.90-0.92$ & 0.96 & 0.003 & $0.96-0.97$ & 0.95 & 0.008 & $0.93-0.96$ \\
\hline Male & 2009 & 0.92 & 0.007 & $0.90-0.93$ & 0.96 & 0.003 & $0.96-0.97$ & 0.95 & 0.007 & $0.94-0.97$ \\
\hline Male & 2010 & 0.90 & 0.007 & $0.88-0.91$ & 0.96 & 0.003 & $0.96-0.97$ & 0.93 & 0.008 & $0.92-0.95$ \\
\hline Male & 2011 & 0.88 & 0.007 & $0.87-0.90$ & 0.96 & 0.003 & $0.96-0.97$ & 0.92 & 0.008 & $0.90-0.93$ \\
\hline Male & 2012 & 0.89 & 0.007 & $0.88-0.90$ & 0.96 & 0.003 & $0.96-0.97$ & 0.93 & 0.008 & $0.91-0.94$ \\
\hline Male & 2013 & 0.89 & 0.007 & $0.88-0.91$ & 0.96 & 0.003 & $0.96-0.97$ & 0.93 & 0.008 & $0.91-0.94$ \\
\hline Male & 2014 & $\mathrm{C}$ & NA & NA & 0.96 & 0.003 & 0.96-0.97 & NA & NA & NA \\
\hline
\end{tabular}


The encounter histories for the recruitment analysis included the same individuals as the survival analysis, but only included physical recaptures of those individuals. As a result, the density of the encounter histories and the size of the model set were much reduced. Model selection statistics were adjusted with a small overdispersion correction factor ( $\hat{c})$ of 1.14 and indicated almost no model selection uncertainty. The best model accounted for all of the weight in the model set $\left(w_{i}=1.00\right)$ and included separate $\gamma$ parameters for each sex but did not include a year effect. This model included both a sex and year effect on $p$ (table 5). Model-averaged estimates of $p$ were low and mostly similar to estimates from the survival analysis for the years prior to implementation of the remote PIT tag detection systems. Estimates for females ranged from 0.01 to 0.06. Estimates for males ranged from 0.07 to 0.14 , except for the most recent 4 years when estimates were $0.22-0.30$. Model-averaged $\gamma$ estimates indicated consistently low levels of recruitment of new spawners into the subpopulation (table 4). In every year from 2002 to 2013 , point estimates of seniority were slightly higher than estimates of apparent survival such that derived annual estimates of population rate of change $(\lambda)$ were less than 1.0 (table 4). Compounding the 13 estimates of $\lambda$ indicates that the abundance of female LRS in this subpopulation decreased by 53 percent $\left(\Delta_{t}=0.47\right)$ and the abundance of male LRS decreased by 59 percent $\left(\Delta_{t}=0.41\right)$ through 2013 (fig. 2).

The fork length data collected over the past 17 years at the lakeshore spawning sites suggest that this subpopulation consists almost entirely of similarly sized individuals growing through time, with little evidence of recruitment. Therefore, we consider the overall estimates of population decline based on derived $\lambda$ estimates to be optimistic; that is, the declines may be more substantial than these estimates indicate. Indeed, the length data show that few individuals of either sex collected since 1999 could be considered new recruits to the spawning population (fig. 3 ).

The time series of fork length data presented in Janney and others (2008) included data back to 1987 and showed that this subpopulation "turned over" during the early to mid-1990s. Prior to 1990, the subpopulation was rather homogeneous and was composed of relatively old, large individuals (males about $650 \mathrm{~mm}$ FL; females about $725 \mathrm{~mm}$ FL). Recruitment in the late 1980s to early 1990s, coupled with substantial losses of adults in large fish die-offs in 1995, 1996, and 1997, resulted in relatively young and small populations in the late 1990s and early 2000s. This .subpopulation apparently is now composed of a subset of the same individuals that were present in the early 2000s. In 2015, the median fork length of males was $655 \mathrm{~mm}$ and the median fork length of females was $718 \mathrm{~mm}$, and individuals of both sexes showed relatively little variability in size. 
Table 5. Model selection results for the reverse time Cormack-Jolly-Seber (seniority) capture-recapture models fitted to the data for adult sucker populations in Upper Klamath Lake, Oregon.

[Akaike's Information Criterion corrected for small sample size and overdispersion (quasilikelihood AICc [QAICc]) was used to compare the candidate models of seniority $(\gamma)$ and re-encounter $(p)$ probabilities. The overdispersion correction factor, $\hat{c}$, is given for each model set. Twenty-five models were fitted to the data from each population, but only plausible models ( $\triangle$ QAICc less than 20) are shown. In the model names, a $\times$ symbol indicates fully interactive effects and the + symbol indicates additive effects. The best model in each set is presented first, and $\Delta \mathrm{QAICc}$ values are the difference between the QAICc value of a given model and that of the best model. Akaike weights $\left(w_{\mathrm{i}}\right)$ provide a measure of the relative weight of each model or the likelihood of it being the best model in the set given the data. Number of parameters $(K)$ is the total number that is theoretically estimable in the model]

\begin{tabular}{|c|c|c|c|c|c|}
\hline Model & $K$ & QAICC & $\triangle Q A I C c$ & $w_{i}$ & $-2 \log _{\mathrm{e}} L$ \\
\hline \multicolumn{6}{|c|}{ Lakeshore Spawning Lost River Suckers, 1999-2015 ( $\hat{\mathbf{c}}=1.14)$} \\
\hline$\gamma(\operatorname{sex}) p(\operatorname{sex} \times$ time $)$ & 34 & $51,077.8$ & 0.0 & 1.00 & $58,151.1$ \\
\hline$\gamma($ sex + time $) p($ sex $\times$ time $)$ & 48 & $51,091.9$ & 14.1 & 0.00 & $58,135.1$ \\
\hline$\gamma() p.(\operatorname{sex} \times$ time $)$ & 33 & $51,092.3$ & 14.5 & 0.00 & $58,169.9$ \\
\hline \multicolumn{6}{|c|}{ River Spawning Lost River Suckers, 2000-15 ( $\hat{\mathbf{c}=1.35)}$} \\
\hline$\gamma($ sex + time $) p(\operatorname{sex} \times$ time $)$ & 45 & $44,677.8$ & 0.0 & 0.50 & $60,193.5$ \\
\hline$\gamma($ sex + time $) p($ time $)$ & 30 & $44,678.7$ & 0.9 & 0.32 & $60,235.3$ \\
\hline$\gamma($ sex + time $) p($ sex + time $)$ & 31 & $44,681.0$ & 3.2 & 0.10 & $60,235.6$ \\
\hline$\gamma($ time $) p($ sex $\times$ time $)$ & 44 & $44,681.5$ & 3.6 & 0.08 & $60,201.10$ \\
\hline$\gamma($ time $) p($ sex + time $)$ & 30 & $44,688.0$ & 10.2 & 0.00 & $60,247.8$ \\
\hline \multicolumn{6}{|c|}{ Shortnose Suckers, 1999-2015 ( $\hat{\mathbf{c}}=1.12)$} \\
\hline$\gamma($ sex + time $) p(\operatorname{sex} \times$ time $)$ & 48 & $43,450.1$ & 0.0 & 0.91 & $48,556.4$ \\
\hline$\gamma(\operatorname{sex}) p(\operatorname{sex} \times$ time $)$ & 34 & $43,455.6$ & 5.5 & 0.06 & $48,594.0$ \\
\hline$\gamma($ time $) p($ sex $\times$ time $)$ & 47 & $43,457.6$ & 7.5 & 0.02 & $48,567.0$ \\
\hline$\gamma() p.(\operatorname{sex} \times$ time $)$ & 33 & $43,459.0$ & 8.8 & 0.01 & $48,600.0$ \\
\hline
\end{tabular}




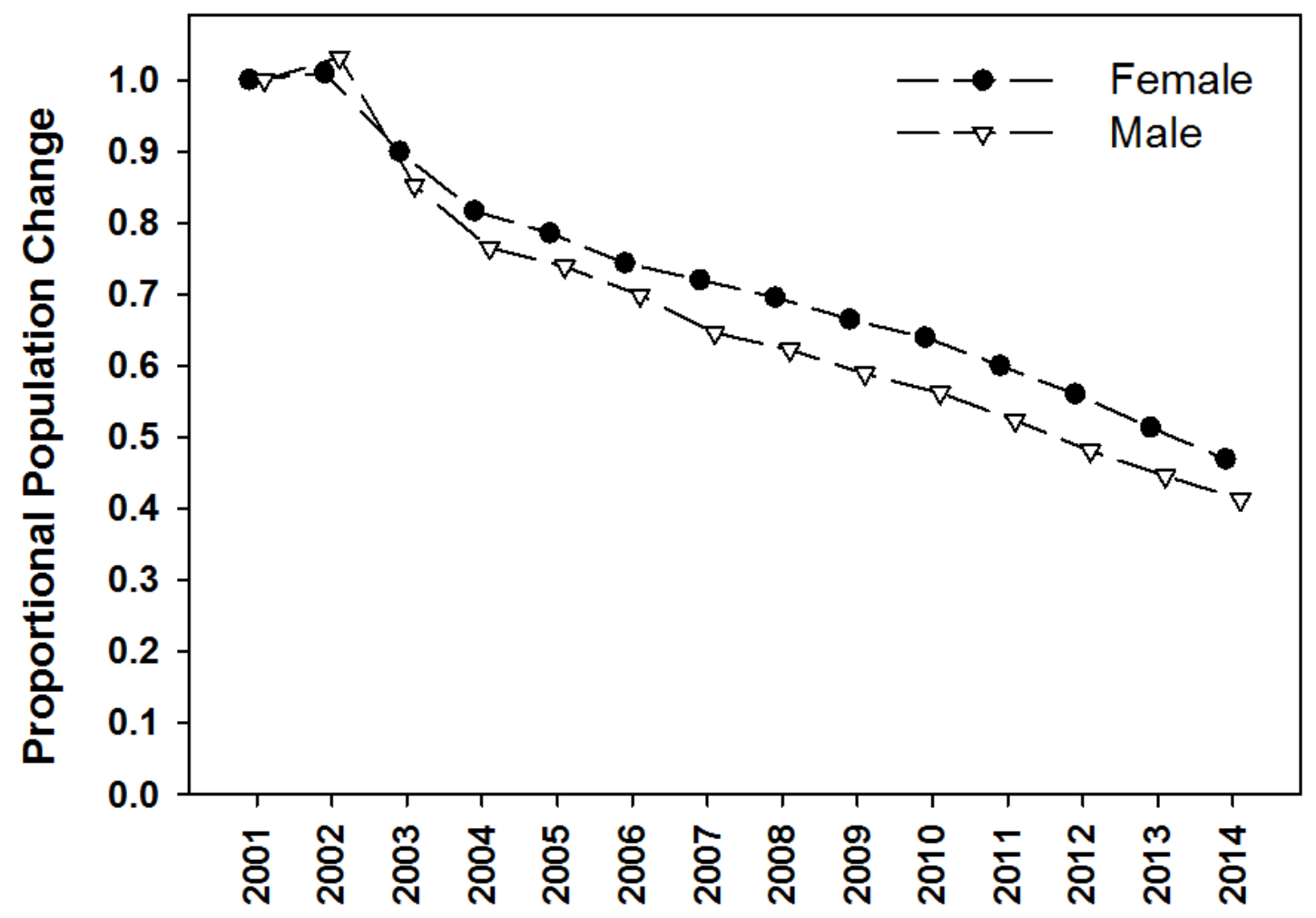

Figure 2. Graph showing realized proportional change in the size of the lakeshore spawning subpopulation of Lost River suckers from 2001 to 2014. Annual changes are based on $\lambda$ estimates derived from separate models of annual apparent survival (Cormack-Jolly-Seber [CJS] likelihood) and seniority (reverse time CJS likelihood) probabilities, using both physical and remote encounters for survival estimates and physical captures only for seniority estimates. 


\section{LRS Springs}

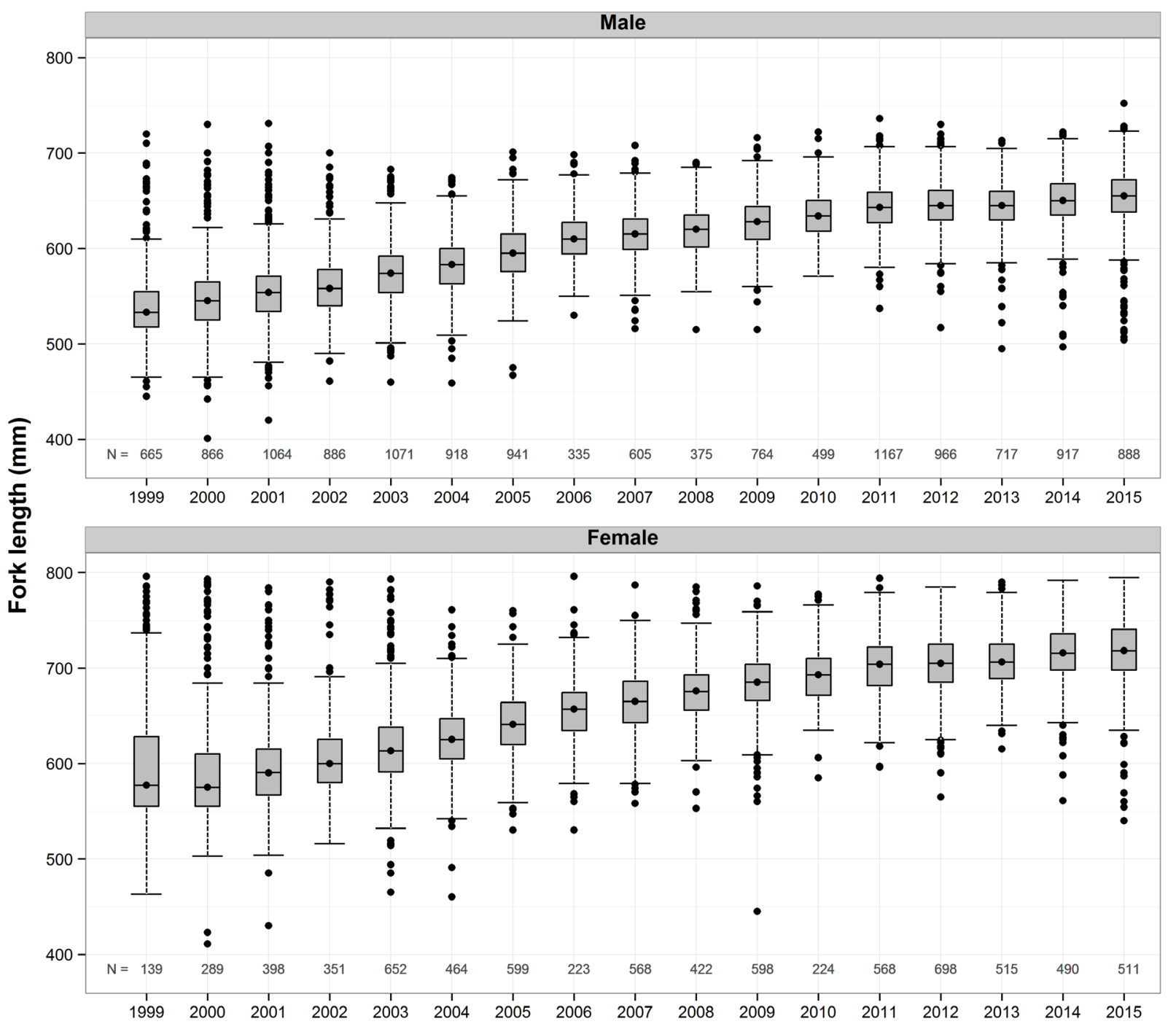

Figure 3. Boxplots showing fork lengths of male and female Lost River suckers captured in trammel nets at lakeshore springs, 1999-2015. Dots in the boxes represent the medians and the boxes cover the central 75 percent of the data. The numbers of fish included in the boxplots for each year are given near the $x$-axis in each panel. 


\section{Williamson and Sprague River Spawning Subpopulation}

From 2000 to 2014, we captured, tagged, and released 21,156 female and 15,117 male LRS in the Williamson River, in the Sprague River, or at pre-spawn staging areas in the lake that were used in our survival analysis. Excluding re-encounters in the year of tagging, we subsequently recaptured or remotely detected 18,959 (90 percent) of the females and 13,141 (87 percent) of the males on at least one occasion through 2015. Models in the recruitment analysis for this subpopulation included additional data from 1,847 females and 1,107 males that were first captured, tagged, and released in 2015.

Model selection statistics for the 35 CJS models fitted to the encounter histories for this subpopulation indicated that the most parameterized model (that is, the global model) received all the support $\left(w_{i}=1.00\right.$; table 3$)$. This model included separate survival $(\Phi)$ parameters for each sex in each year, separate re-encounter probabilities $(p)$ for each sex in each year, and separate tag type effects on $p$ for each sex in each year since 2006. Because of the unequivocal support for the top model in model selection, model-averaged parameter estimates were the same as those from the top model. The estimates of $\Phi$ for males in 2005 and both sexes in 2001 and 2004 were on the boundary at 1.0, indicating estimability problems (table 6). Survival of females generally was high (greater than 0.90 ) except for 2000 (table 6). In contrast, males showed greater variation in annual survival and experienced several years of relatively poor survival (2000, 2006, and 2012; table 6). During 2001-04, prior to use of the remote PIT tag detection systems, estimates of $p$ for males and females were similar and ranged between 0.02 and 0.07. In 2005, the remote antennas in the traps at the Williamson River weir increased the estimate for females to 0.45 and the estimate for males to 0.42 . Estimates of $p$ for both tag types were lower in $2006(0.17-0.33)$ because high flows compromised the detection efficiency of the antennas in the weir traps. Estimates of $p$ during 2007-2012 for fish tagged with $125 \mathrm{kHz}$ PIT tags were similar to 2005 and 2006 estimates depending on the year, and were usually higher for females $(0.23-$ 0.43 ) than males (0.18-0.45). Estimates for both sexes increased substantially in 2013 and 2014, to 0.71 and 0.68 for females and 0.66 for males in both years. Finally, estimates of $p$ for males and females tagged with $134 \mathrm{kHz}$ tags were similar during 2007-14, ranging between 0.78 and 0.97 . Re-encounter probabilities for fish tagged with $134 \mathrm{kHz}$ tags were less variable because more of the remote detection systems in the tributaries could detect those tags, particularly the river-wide array just upstream of the weir that was first installed in 2007. In contrast, the only systems that could detect the $125 \mathrm{kHz}$ tags were the antennas in the weir and the fish ladder at Chiloquin Dam. The antennas in the weir provided all detections for $125 \mathrm{kHz}$ tags following the removal of the dam in late summer and autumn of 2008.

The encounter histories for the recruitment analysis were handled in the same way as for the lakeshore spawning subpopulation. Model selection statistics were adjusted with a $\hat{c}$ value of 1.35 . The best model, which accounted for one-half of the weight in the model set $\left(w_{i}=0.50\right)$, included an additive effect of sex and year for the seniority estimates (table 5). This model included separate $p$ parameters for each sex in each year. The second best model $\left(w_{i}=0.32\right)$ included the same parameter structure for seniority but no sex effect for $p$. Model-averaged estimates of $p$ were low and similar between males and females, ranging between 0.02 and 0.12 with an average of 0.04 . 
Table 6. Demographic parameter estimates for Lost River suckers from the river spawning subpopulation, Upper Klamath Lake, Oregon.

[Model-averaged estimates of annual apparent survival probabilities $(\Phi)$ and seniority probabilities $(\gamma)$, the derived estimates of annual population rate of change ( $\lambda$ ), and the estimated standard errors (SE) and 95 percent confidence intervals (CI) for all estimates. Confounded parameters $(\mathrm{C})$ and estimates on the boundary at $1.0(\mathrm{~B})$ are shaded gray]

\begin{tabular}{|c|c|c|c|c|c|c|c|c|c|c|}
\hline Sex & Year & $\Phi$ Est & $\Phi$ SE & $\Phi \mathrm{Cl}$ & $\gamma$ Est & $\gamma \mathrm{SE}$ & $\gamma \mathrm{Cl}$ & $\lambda$ Est & $\lambda \mathrm{SE}$ & $\lambda \mathrm{Cl}$ \\
\hline Female & 2000 & 0.88 & 0.037 & $0.78-0.93$ & $\mathrm{C}$ & NA & NA & NA & NA & NA \\
\hline Female & 2001 & B & NA & NA & NA & NA & NA & NA & NA & NA \\
\hline Female & 2002 & 0.91 & 0.022 & $0.86-0.95$ & B & NA & NA & 0.91 & 0.022 & $0.86-0.95$ \\
\hline Female & 2003 & 0.90 & 0.017 & $0.86-0.93$ & 0.82 & 0.067 & $0.65-0.92$ & 1.10 & 0.092 & $0.92-1.28$ \\
\hline Female & 2004 & B & NA & NA & B & NA & NA & NA & NA & NA \\
\hline Female & 2005 & 0.96 & 0.010 & $0.93-0.97$ & B & NA & NA & 0.96 & 0.010 & $0.93-0.97$ \\
\hline Female & 2006 & 0.93 & 0.007 & 0.91-0.94 & 0.38 & 0.022 & $0.34-0.43$ & 2.43 & 0.141 & $2.15-2.70$ \\
\hline Female & 2007 & 0.95 & 0.005 & $0.94-0.96$ & B & NA & NA & 0.95 & 0.005 & $0.94-0.96$ \\
\hline Female & 2008 & 0.93 & 0.004 & $0.92-0.94$ & 0.58 & 0.041 & $0.50-0.66$ & 1.60 & 0.112 & $1.38-1.82$ \\
\hline Female & 2009 & 0.95 & 0.003 & $0.94-0.96$ & 0.90 & 0.058 & $0.72-0.97$ & 1.06 & 0.069 & $0.93-1.20$ \\
\hline Female & 2010 & 0.93 & 0.003 & $0.92-0.94$ & B & NA & NA & 0.93 & 0.003 & $0.92-0.94$ \\
\hline Female & 2011 & 0.92 & 0.003 & $0.91-0.93$ & B & NA & NA & 0.92 & 0.003 & $0.91-0.93$ \\
\hline Female & 2012 & 0.91 & 0.003 & 0.91-0.92 & 0.89 & 0.033 & $0.79-0.94$ & 1.03 & 0.044 & $0.95-1.12$ \\
\hline Female & 2013 & 0.91 & 0.003 & $0.91-0.92$ & B & NA & NA & 0.91 & 0.003 & $0.91-0.92$ \\
\hline Female & 2014 & $\mathrm{C}$ & NA & NA & B & NA & NA & NA & NA & NA \\
\hline Male & 2000 & 0.70 & 0.043 & $0.61-0.78$ & $\mathrm{C}$ & NA & NA & NA & NA & NA \\
\hline Male & 2001 & B & NA & NA & NA & NA & NA & NA & NA & NA \\
\hline Male & 2002 & 0.93 & 0.029 & $0.85-0.97$ & B & NA & NA & 0.93 & 0.029 & $0.85-0.97$ \\
\hline Male & 2003 & 0.89 & 0.022 & $0.84-0.93$ & 0.80 & 0.073 & $0.62-0.90$ & 1.12 & 0.106 & $0.91-1.33$ \\
\hline Male & 2004 & B & NA & NA & B & NA & NA & NA & NA & NA \\
\hline Male & 2005 & B & NA & NA & B & NA & NA & NA & NA & NA \\
\hline Male & 2006 & 0.81 & 0.009 & $0.79-0.83$ & 0.35 & 0.023 & $0.30-0.39$ & 2.33 & 0.155 & $2.03-2.64$ \\
\hline Male & 2007 & 0.96 & 0.005 & $0.95-0.97$ & B & NA & NA & 0.96 & 0.005 & $0.95-0.97$ \\
\hline Male & 2008 & 0.93 & 0.006 & $0.92-0.94$ & 0.55 & 0.042 & $0.46-0.63$ & 1.70 & 0.131 & $1.44-1.96$ \\
\hline Male & 2009 & 0.90 & 0.005 & $0.89-0.91$ & 0.88 & 0.065 & $0.69-0.96$ & 1.02 & 0.076 & $0.87-1.17$ \\
\hline Male & 2010 & 0.92 & 0.004 & $0.92-0.93$ & B & NA & NA & 0.92 & 0.004 & $0.92-0.93$ \\
\hline Male & 2011 & 0.92 & 0.004 & $0.91-0.93$ & B & NA & NA & 0.92 & 0.004 & $0.91-0.93$ \\
\hline Male & 2012 & 0.86 & 0.005 & $0.85-0.87$ & 0.87 & 0.042 & $0.76-0.93$ & 0.99 & 0.048 & $0.89-1.08$ \\
\hline Male & 2013 & 0.91 & 0.004 & $0.90-0.92$ & B & NA & NA & 0.91 & 0.004 & $0.90-0.92$ \\
\hline Male & 2014 & $\mathrm{C}$ & NA & NA & B & NA & NA & NA & NA & NA \\
\hline
\end{tabular}


All models in the set that received support included effects that showed temporal variation in seniority. In all models, the $\gamma$ estimate for 8 of the 13 years $(2002,2004,2005,2007,2010,2011,2013$, and 2014) was on the boundary at 1.0 even though these years were constrained to a single parameter. The model-averaged estimates of seniority indicated that in 2003, 2006, 2008, 2009, and 2012, the percentage of individuals of each sex in this subpopulation that were newly recruited to the spawning population ranged from 10 to 65 percent (table 6 ). In contrast to these estimates, the fork length data collected over the past 16 years show that few individuals small enough to be considered new recruits were captured in any of those years (fig. 4). An issue with sampling in the Chiloquin Dam fish ladder during the high flows of 2006 is responsible for the biased seniority estimates in that year (Hewitt and others, 2011). The low estimates of seniority in the other years are likely biased by a combination of factors related to the difficulty in monitoring this subpopulation by capture-recapture. We return to this issue in section, "Discussion," but note here that we view these low seniority estimates with considerable skepticism. Although the estimates of $\gamma$ for more than one-half of the years in the study were on the boundary at 1.0, which to some extent indicates problems with estimation, the length data suggest that it is reasonable that there was little recruitment of new individuals in those years. Furthermore, even if some new recruits entered the spawning population in some years, the small $\gamma$ estimates that indicate large recruitment events in 2006 and 2008 contrast sharply with the length data. Therefore, we regard the estimates of $\lambda$ for those years and the increasing trend in abundance that they imply as highly improbable (increases of more than 300 percent for both sexes since 2002; table 6). Rather, the overall trend in abundance probably is better characterized (if somewhat pessimistic) by assuming that no recruitment occurred in any year between 2002 and $2013(\gamma=1.0, \lambda=\Phi)$. Calculated in this way, the abundance of females in this subpopulation may have decreased by as much as 56 percent $\left(\Delta_{t}=0.44\right)$, and the abundance of males may have decreased by as much as 64 percent $\left(\Delta_{t}=0.36\right)$ through 2014 .

The time series of fork length data provided in Janney and others (2008) showed that river spawning LRS went through a demographic transition similar to that experienced by lakeshore spawning LRS. In the mid-1980s, this subpopulation was rather homogeneous and was composed of relatively old, large individuals (males about $620 \mathrm{~mm}$ FL; females about $675 \mathrm{~mm}$ FL), although somewhat smaller than individuals in the lakeshore spawning subpopulation. As a result of recruitment in the late 1980s to early 1990s, and losses of adults in fish die-offs in 1995, 1996, and 1997, the subpopulation was composed of relatively young and small individuals by the late 1990s. A subset of those individuals apparently now makes up most of the current spawning population. In 2015, the median fork length of males was $623 \mathrm{~mm}$ and the median fork length of females was $684 \mathrm{~mm}$. Individuals of both sexes show relatively little variability in size, and although some small fish collected at pre-spawn staging areas are evident in some years, these smaller fish never make up a large part of the sample. 


\section{LRS River}

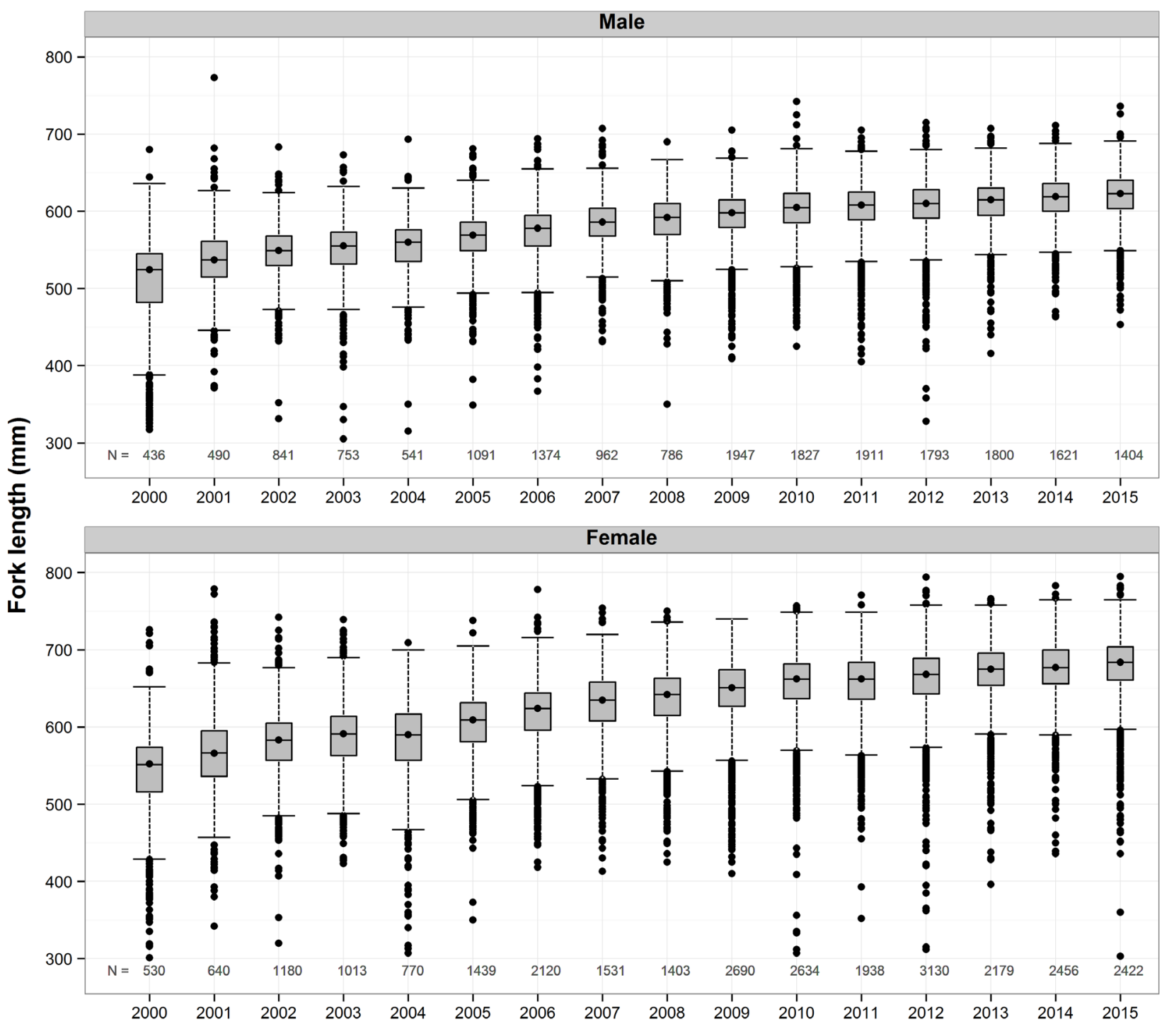

Figure 4. Boxplots of fork lengths of male and female Lost River suckers captured at pre-spawn staging areas in Upper Klamath Lake and in the Williamson and Sprague Rivers, 2000-2015. Dots in the boxes represent the medians and the boxes cover the central 75 percent of the data. The numbers of fish included in the boxplots for each year are given near the $x$-axis in each panel. 


\section{Shortnose Suckers}

\section{Catch Summary for 2015}

Trammel net sampling at the lakeshore springs captured only three SNS (table 1). All three of these individuals were also detected in the Williamson River during the spawning season. In total, the remote PIT tag antennas at the lakeshore springs detected 40 individual SNS during the spawning season, with most of those detections occurring at Cinder Flats and Sucker Springs (table 2). Of the 40 individuals detected, 31 (78 percent) also were detected in the Williamson River in 2015. Six of the nine fish that were not detected in the Williamson River in 2015 had been detected in the river in past years. Only three of the SNS detected at the springs, one female and two males, had encounter histories without encounters in the Williamson River. Additionally, 27 individuals were detected at the lakeshore springs that were originally tagged in Lake Ewauna and transplanted to the Williamson River in the 2015 spawning season.

We captured 2,114 SNS in trammel nets at pre-spawn staging areas, and 919 of these individuals had been tagged prior to the 2015 sampling season. The percentage of SNS captured at the staging areas that were previously tagged increased steadily from 9 percent in 2003 to 44 percent in 2014 and then decreased slightly to 43 percent in 2015 (table 1). Eight individuals were recaptured for their first reencounter since they were tagged in 1999-2001. In addition, captures of one male that was originally tagged and released in 1995 and one male originally tagged and released in 1996 represented their first re-encounters after 20 and 19 years, respectively. Of the PIT-tagged SNS captured at the staging areas, 82 percent were subsequently captured or detected somewhere in the Williamson or Sprague Rivers, whereas only twelve individuals ( $<1$ percent) were later encountered at the lakeshore springs. Eight of the 12 individuals also were encountered in the Williamson or Sprague Rivers in 2015.

A total of 338 SNS were captured in the upstream trap of the Williamson River weir (table 1). The catch on April 29 accounted for 27 percent of the total catch during the season. Of the 338 SNS captured, 123 had been tagged prior to the 2015 sampling season. The percentage of SNS captured in the weir that were previously tagged increased from 13 percent in 2005 to 37 percent in 2014, then decreased to 36 percent in 2015, and continues to be smaller than the recapture percentage at the staging areas. The remote PIT tag antennas at the weir combined to detect a total of 6,428 individual SNS (table 2). Similar to past years, the seasonal pattern of the run timing for SNS was responsive to water temperature; most individuals were captured and detected at the weir during three time periods (late March, mid-April, and late April/early May) when temperatures were approaching or exceeding $12{ }^{\circ} \mathrm{C}$.

Upstream of the Williamson River weir, the river-wide antenna array in the Sprague River just downstream of the Chiloquin Dam site detected 533 individual SNS (table 2). The most upstream antenna array, located upstream of the Chiloquin Dam site, detected 158 SNS.

\section{Survival, Recruitment, and Size Composition}

From 1999 to 2014, we captured, tagged, and released 12,547 female and 6,831 male SNS. Excluding re-encounters in the year of tagging, we subsequently recaptured or remotely detected 8,591 (68 percent) of the females and 4,357 (64 percent) of the males on at least one occasion through 2015. Models in the recruitment analysis included additional data from 844 females and 548 males that were first captured and tagged in 2015. 
Thirty-five CJS models were fitted to the SNS encounter histories to estimate apparent annual survival and re-encounter probabilities. The top model in the set accounted for all of the weight in the model set $\left(w_{i}=1.0\right.$; table 3$)$. This model included separate $\Phi$ parameters for each sex in each year, and sex, year, and tag type effects for $p$. Because of the unequivocal support for the top model in model selection, model-averaged parameter estimates were the same as those from the top model. Estimates of $\Phi$ showed that survival has been similar between the sexes in recent years, but female survival was substantially higher than male survival in 2002 and 2006 (table 7). Female survival was estimated to be substantially lower than survival for males only in 2003. Overall, annual variation in survival was greater for SNS than for either subpopulation of LRS. Survival for both sexes was low during 2001, 2004, and 2010-2012. Survival also was low for females in 2003 and for males in 2002 and 2006.

Estimates of re-encounter probabilities in 2014 were similar to those in 2013, and a complete discussion of the changes in estimates of $p$ over time are reported in Hewitt and others (2015).

The encounter histories and modeling for the recruitment analysis were handled in the same way as for LRS. Model selection statistics were adjusted with a $\hat{c}$ value of 1.12. The best model, which accounted for most of the weight in the model set $\left(w_{i}=0.91\right)$, included an additive effect of sex and year for the $\gamma$ estimates (table 5). The other three models with some support included a model with only a sex effect on seniority $\left(w_{i}=0.06\right)$, a model with only a year effect $\left(w_{i}=0.02\right)$, and a model with no effects on seniority $\left(w_{i}=0.01\right)$. All four of these models included separate $p$ parameters for each sex in each year. Model-averaged estimates of $p$ were low and similar between males and females, ranging between 0.02 and 0.12 and generally increasing over the course of the study. Similar to river spawning LRS, the model that received the vast majority of support included temporal variation in seniority. However, 6 of the 14 seniority estimates (2001-05 and 2007) were estimated on the boundary at 1.0 despite being constrained to a single parameter.

The model-averaged estimates of seniority indicated that no substantial recruitment occurred in most of the early years of the study $(2001-05,2007)$. In the other years of the study, the estimated percentage of individuals that were newly recruited to the spawning population was 4-15 percent for females and 5-20 percent for males (table 7). As with river spawning LRS, the low estimates of seniority in 2006 likely are biased low by an issue with sampling in the Chiloquin Dam fish ladder (Hewitt and others, 2011). Derived estimates of $\lambda$ for 2008 and 2009 were imprecise and the confidence intervals broadly overlapped 1.0, but the point estimates indicated slight increases in the size of the spawning population (table 7; fig. 5). However, the size of the spawning population declined substantially in 2010 and the overall trend between 2001 and 2014 is negative. Compounding the 13 estimates of $\lambda$ indicates that the abundance of female SNS decreased by 74 percent $\left(\Delta_{t}=0.26\right)$, and the abundance of male SNS decreased by 77 percent $\left(\Delta_{t}=0.23\right)$ through 2014 (fig. 5). 


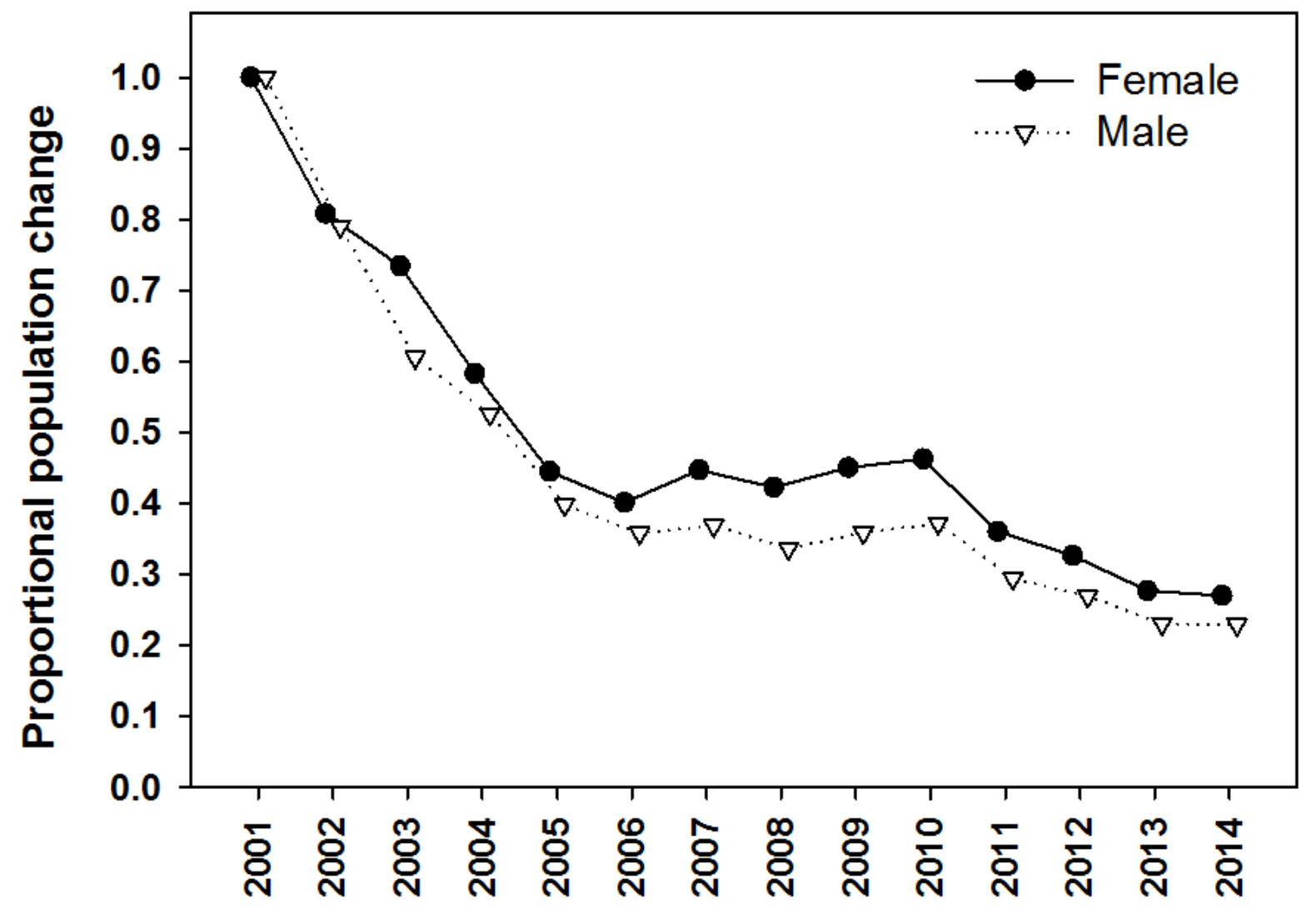

Figure 5. Graph showing realized proportional change in the size of the shortnose sucker spawning population from 2001 to 2014. Annual changes are based on $\lambda$ estimates derived from separate models of annual apparent survival (Cormack-Jolly-Seber [CJS] likelihood) and seniority (reverse time CJS likelihood) probabilities, using both physical and remote encounters for survival estimates and physical captures only for seniority estimates. 
Fork length data collected over the past 16 years for SNS suggests that the population consists almost entirely of similarly sized individuals, with evidence of only sparse recruitment (fig. 6). This evidence contrasts with the recent seniority estimates $(2006,2008,2009,2011,2013$, and 2014) that indicate substantial recruitment of new individuals into the spawning population. Recruitment analyses for SNS share some of the difficulties with capture-recapture monitoring that was seen for river spawning LRS, although to a lesser degree. Again, we defer a full account of these issues to section, "Discussion," but these issues lead us to caution that the overall trend in spawning population size could be more negative than indicated by the derived $\lambda$ estimates.

The time series of fork length data provided in Janney and others (2008) included data back to 1984 and showed that the SNS population in Upper Klamath Lake went through a demographic transition similar to that for LRS. In the mid-1980s, the SNS population was rather homogeneous and was composed of relatively old and large individuals (males about $425 \mathrm{~mm}$ FL; females about $450 \mathrm{~mm} \mathrm{FL}$ ). The population then "turned over" as a result of recruitment in the late 1980s to early 1990s and losses of adults in fish die-offs in 1995, 1996, and 1997. The current population is mostly a subset of the individuals that were present in the late 1990s. Both male and female SNS have grown little since 2009 (Hewitt and others, 2012; fig. 6), and the median fork length of each sex is now similar to what it was in the mid-1980s (males about $433 \mathrm{~mm}$; females about $460 \mathrm{~mm}$ ). 
Table 7. Demographic parameter estimates for the shortnose sucker spawning population, Upper Klamath Lake, Oregon.

[Model-averaged estimates of annual apparent survival probabilities $(\Phi)$ and seniority probabilities $(\gamma)$, the derived estimates of annual population rate of change ( $\lambda$ ), and the estimated standard errors (SE) and 95 percent confidence intervals (CI) for all estimates. Confounded parameters (C) and estimates on the boundary at $1.0(\mathrm{~B})$ are shaded gray]

\begin{tabular}{|c|c|c|c|c|c|c|c|c|c|c|}
\hline Sex & Year & $\Phi$ Est & $\Phi$ SE & $\Phi \mathrm{Cl}$ & $\gamma$ Est & $\gamma \mathrm{SE}$ & $\gamma \mathrm{Cl}$ & $\lambda$ Est & $\lambda \mathrm{SE}$ & $\lambda \mathrm{Cl}$ \\
\hline Female & 1999 & 0.68 & 0.179 & $0.30-0.92$ & $\mathrm{C}$ & NA & NA & NA & NA & NA \\
\hline Female & 2000 & 0.70 & 0.060 & $0.57-0.80$ & NA & NA & NA & NA & NA & NA \\
\hline Female & 2001 & 0.81 & 0.043 & $0.71-0.88$ & B & NA & NA & 0.81 & 0.043 & $0.71-0.88$ \\
\hline Female & 2002 & 0.91 & 0.048 & $0.76-0.97$ & B & NA & NA & 0.91 & 0.048 & $0.76-0.97$ \\
\hline Female & 2003 & 0.79 & 0.036 & $0.71-0.86$ & B & NA & NA & 0.79 & 0.036 & $0.71-0.86$ \\
\hline Female & 2004 & 0.76 & 0.021 & $0.72-0.80$ & B & NA & NA & 0.76 & 0.021 & $0.72-0.80$ \\
\hline Female & 2005 & 0.90 & 0.013 & $0.87-0.92$ & B & NA & NA & 0.90 & 0.013 & $0.87-0.92$ \\
\hline Female & 2006 & 0.92 & 0.009 & $0.90-0.94$ & 0.85 & 0.045 & $0.74-0.92$ & 1.09 & 0.058 & $0.97-1.20$ \\
\hline Female & 2007 & 0.95 & 0.006 & $0.93-0.96$ & B & NA & NA & 0.95 & 0.006 & $0.93-0.96$ \\
\hline Female & 2008 & 0.92 & 0.006 & $0.91-0.93$ & 0.86 & 0.047 & $0.74-0.93$ & 1.07 & 0.060 & $0.95-1.18$ \\
\hline Female & 2009 & 0.91 & 0.007 & $0.89-0.92$ & 0.90 & 0.043 & $0.78-0.96$ & 1.01 & 0.049 & $0.91-1.10$ \\
\hline Female & 2010 & 0.76 & 0.008 & $0.74-0.77$ & 0.96 & 0.041 & $0.74-1.00$ & 0.79 & 0.034 & $0.71-0.85$ \\
\hline Female & 2011 & 0.81 & 0.007 & $0.79-0.82$ & 0.91 & 0.037 & $0.80-0.96$ & 0.89 & 0.037 & $0.82-0.96$ \\
\hline Female & 2012 & 0.79 & 0.007 & $0.78-0.81$ & 0.95 & 0.038 & $0.80-0.99$ & 0.83 & 0.034 & $0.77-0.90$ \\
\hline Female & 2013 & 0.86 & 0.006 & $0.85-0.87$ & 0.89 & 0.040 & $0.78-0.94$ & 0.97 & 0.044 & $0.88-1.05$ \\
\hline Female & 2014 & $\mathrm{C}$ & NA & NA & 0.93 & 0.036 & $0.82-0.97$ & NA & NA & NA \\
\hline Male & 1999 & 0.71 & 0.175 & $0.32-0.93$ & $\mathrm{C}$ & NA & NA & NA & NA & NA \\
\hline Male & 2000 & B & NA & NA & NA & NA & NA & NA & NA & NA \\
\hline Male & 2001 & 0.79 & 0.060 & $0.65-0.88$ & B & NA & NA & 0.79 & 0.060 & $0.65-0.88$ \\
\hline Male & 2002 & 0.77 & 0.061 & $0.63-0.87$ & B & NA & NA & 0.77 & 0.061 & $0.63-0.87$ \\
\hline Male & 2003 & 0.87 & 0.059 & $0.71-0.95$ & B & NA & NA & 0.87 & 0.059 & $0.71-0.95$ \\
\hline Male & 2004 & 0.76 & 0.035 & $0.68-0.82$ & B & NA & NA & 0.76 & 0.035 & $0.68-0.82$ \\
\hline Male & 2005 & 0.90 & 0.022 & $0.85-0.94$ & B & NA & NA & 0.90 & 0.022 & $0.85-0.94$ \\
\hline Male & 2006 & 0.82 & 0.016 & $0.78-0.85$ & 0.80 & 0.057 & $0.67-0.89$ & 1.02 & 0.075 & $0.87-1.17$ \\
\hline Male & 2007 & 0.91 & 0.010 & $0.89-0.93$ & B & NA & NA & 0.91 & 0.010 & $0.89-0.93$ \\
\hline Male & 2008 & 0.89 & 0.011 & $0.86-0.91$ & 0.82 & 0.062 & $0.67-0.91$ & 1.08 & 0.083 & $0.92-1.24$ \\
\hline Male & 2009 & 0.89 & 0.010 & $0.87-0.91$ & 0.87 & 0.055 & $0.73-0.95$ & 1.02 & 0.066 & $0.89-1.15$ \\
\hline Male & 2010 & 0.76 & 0.011 & $0.74-0.78$ & 0.95 & 0.055 & $0.67-0.99$ & 0.80 & 0.048 & $0.70-0.89$ \\
\hline Male & 2011 & 0.80 & 0.011 & $0.78-0.82$ & 0.88 & 0.049 & $0.74-0.95$ & 0.91 & 0.051 & $0.80-1.01$ \\
\hline Male & 2012 & 0.79 & 0.010 & $0.76-0.81$ & 0.93 & 0.051 & $0.75-0.98$ & 0.84 & 0.048 & $0.75-0.94$ \\
\hline Male & 2013 & 0.85 & 0.009 & $0.83-0.87$ & 0.85 & 0.052 & $0.72-0.93$ & 1.00 & 0.061 & $0.88-1.12$ \\
\hline Male & 2014 & $\mathrm{C}$ & NA & NA & 0.90 & 0.047 & $0.76-0.96$ & NA & NA & NA \\
\hline
\end{tabular}




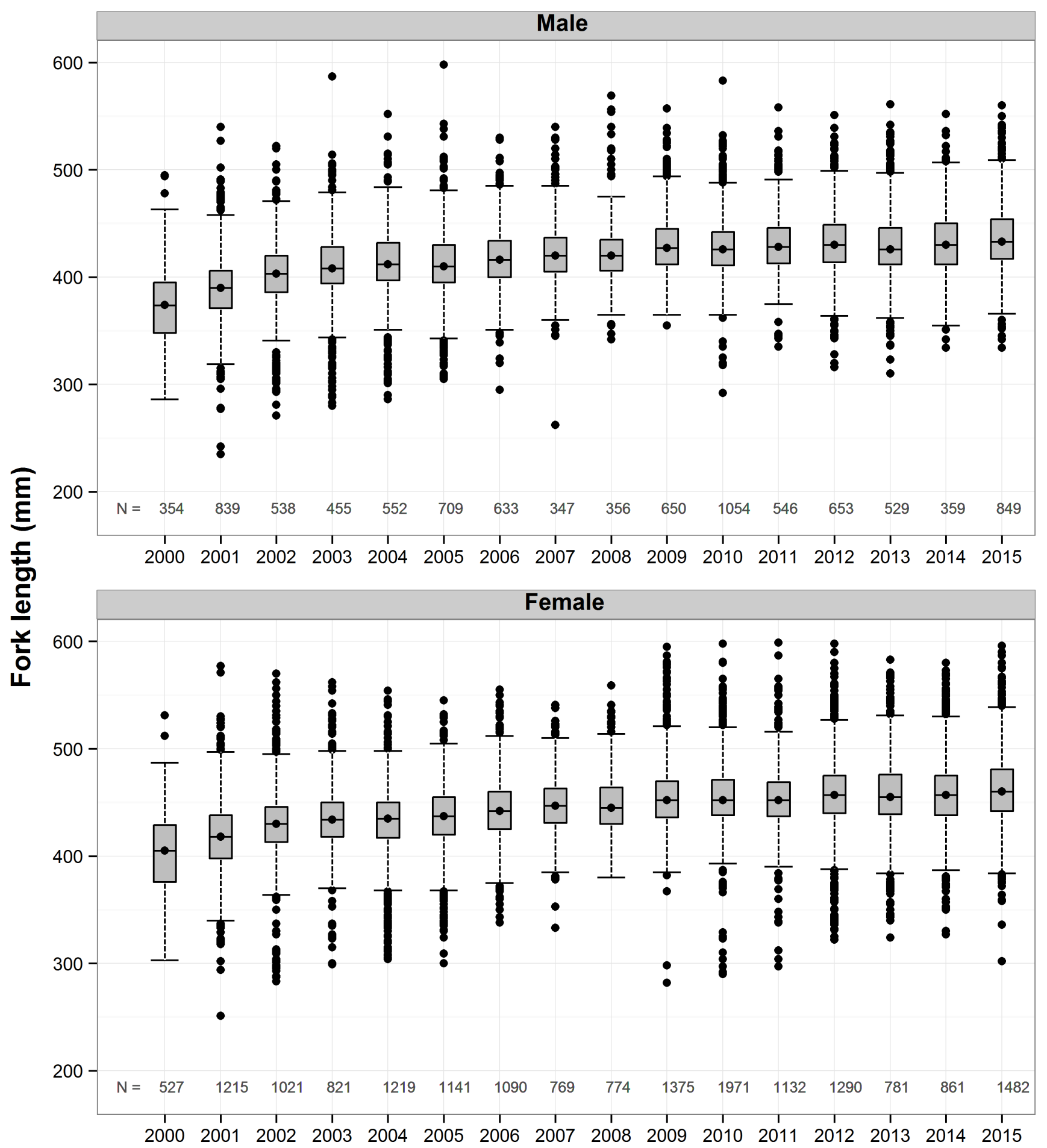

Figure 6. Boxplots showing fork lengths of male and female shortnose suckers captured in Upper Klamath Lake and the Williamson and Sprague Rivers, 2000-2015. Dots in the boxes represent the medians and the boxes cover the central 75 percent of the data. The number of fish included in the boxplots for each year are given near the $x$ axis in each panel. 


\section{Discussion}

Serious concern is warranted for the spawning populations of LRS and SNS in Upper Klamath Lake, and the current situation is most dire for SNS. Capture-recapture results and size composition data show that the abundance of both species has decreased since the early 2000 s, continuing trends documented previously (Hewitt and others, 2011, 2012, 2014, and 2015). The SNS population has decreased more than either subpopulation of LRS, but the abundances of both species probably have decreased by more than 50 percent since the early 2000s. These decreases primarily indicate a lack of recruitment of new individuals into the spawning populations, but capture-recapture estimates show that both species have experienced some years with relatively poor survival as well. The decrease in abundance for SNS was estimated to be more than 70 percent since 2001, and SNS have experienced more years with poor survival than either subpopulation of LRS.

Most of the suckers in the lake were spawned in the early 1990s, meaning that most of the individuals of both species, but especially SNS, have been mature for many years and are now beyond the average expected lifespan for the species. Classical theory suggests that some senescence should be occurring through reduced fecundity, increased mortality, or both (Hamilton, 1966). However, more recent research shows that it is possible for senescence to be negligible or even "negative" for animals such as fish, with so-called indeterminate growth, or growth beyond reproductive maturity (Vaupel and others, 2004; Williams and others, 2006; Finch, 2009; McNamara and others, 2009; Baudisch, 2011; Jones and others, 2014; Wensink and others, 2014). Continued capture-recapture monitoring of survival for the endangered suckers in Upper Klamath Lake will provide evidence about whether senescence occurs through mortality for these populations (for example, Peron and others, 2010).

Despite the worrisome status of the populations, our monitoring shows that the abundance of both species of endangered suckers in Upper Klamath Lake is still at an order of magnitude that affords some protection from widespread mortality events, such as die-offs in the summer and autumn caused by poor water quality (for example, Perkins and others, 2000). Over the course of a spawning season, total counts of PIT-tagged individuals that are either captured in trammel net sampling or detected by the remote PIT tag detection systems provide absolute minimum abundances for the two species. In 2015, we encountered more than 6,350 lakeshore spawning LRS, more than 25,100 river spawning LRS, and more than 6,800 SNS. The true abundances of spawning fish in the populations are certainly larger than these numbers because the recapture percentages from weir and trammel net sampling show that a large proportion of fish in each population is not PIT-tagged. 
Formal estimation of abundance through capture-recapture requires strict attention to modeling variability and heterogeneity in encounter probabilities to avoid biased estimates (Link, 2003; Holzmann and others, 2006; Morgan and Ridout, 2009; Cubaynes and others, 2010; Pledger and others, 2010). Modeling of encounter probabilities typically is the Achilles heel of abundance estimation for large fish populations (Pine and others, 2003; Hewitt and others, 2010). Instead of providing estimates of abundance that are likely to be biased to an unknown degree, our monitoring program focuses on estimating survival and seniority parameters that can track relative changes in abundance through time. Such methods are more robust to issues associated with encounter probabilities than methods for abundance estimation (Lebreton and others, 1992; Marescot and others, 2011). Survival estimates from our program are expected to be particularly robust to heterogeneity in encounter probabilities (Fletcher and Efford, 2009; Fletcher and others, 2012; Abadi and others, 2013). Modeling and estimation of seniority and population rate of change with capture-recapture data is an active area of research (Pradel and others, 2010; Marescot and others, 2011), and estimates of these parameters are more likely to be biased when heterogeneity is present than are estimates of survival (Nichols and others, 2000; Fletcher and others, 2012).

Heterogeneity in encounter probabilities is difficult to detect and account for when encounter probabilities are low because the encounter histories are less informative. Recapture probabilities often are low in studies of large fish populations (Pine and others, 2003), such as those of LRS and SNS in Upper Klamath Lake. Partly as a result of this challenge, most applications of this type of modeling in fisheries research have involved smaller populations of relatively long-lived species (Zehfuss and others, 1999; Pine and others, 2001; Dieterman and others, 2010). Difficulties with estimation in our program arise primarily because the detections from the remote PIT tag antennas cannot be used in estimating seniority parameters, and recapture probabilities based on weir and trammel net sampling alone are smaller than typically is desired for robust capture-recapture inferences. Despite considerable sampling effort each year, recapture probabilities almost always were less than 0.15 and usually were less than 0.10; a good rule of thumb is that recapture probabilities should be greater than 0.20 (Hightower and Gilbert, 1984; Pollock and others, 1990; Hewitt and others, 2010).

Modeling of seniority has been most successful for lakeshore spawning LRS because recruitment has been trivial since our monitoring began and because the nature of those spawning aggregations makes it possible to sample a large proportion of the subpopulation. More than 70 percent of the subpopulation is now PIT-tagged, and goodness-of-fit tests for the models used in the seniority analysis indicated little heterogeneity in recapture probabilities. In contrast, heterogeneity was more apparent in goodness-of-fit tests for models in the seniority analysis for river spawning LRS. Heterogeneity also is indicated by the difference in the percentage of recaptures between the trammel net sampling at the pre-spawn staging areas and captures in the weir trap. The recapture percentage at staging areas always has been greater than at the weir, and has been greater by 10 percent or more every year since 2011. If these sampling efforts target the same statistical population, differences of this magnitude would be unlikely. Some of the observed differences are caused by variability in capture probabilities at the weir. Although we typically capture thousands of river spawning LRS each year, this number represents a relatively small proportion of the total spawning population. Another possibility is that some river spawning LRS do not aggregate at staging areas prior to spawning, or aggregate somewhere else that we do not sample, but nonetheless join the spawning migration and are available for capture at the weir. Finally, some heterogeneity probably derives from fish not being fully independent and instead associating in groups during the spawning season, thus either avoiding capture or being captured together. Indeed, we see this happen at the weir on some days, when numerous LRS are captured but few of them have PIT tags. 
As a result of the heterogeneity in recapture probabilities, estimation and interpretation of seniority and population rate of change are more complicated for the river spawning subpopulation of LRS than for the lakeshore spawning subpopulation of LRS. Some of the seniority estimates are likely biased. Although some recruitment of new spawners is possible, the magnitude of recruitment suggested by the low estimate of seniority in 2008 contrasts strongly with size composition data. The same issues apply to the SNS population, but to a lesser extent, because (1) the SNS population is much smaller than the river spawning subpopulation of LRS, (2) we have captured and tagged a larger proportion of the SNS population, and (3) modeling and estimation indicate a smaller amount of heterogeneity for SNS. Although the seniority estimates for SNS in some recent years are also likely biased low, the derived estimates of $\lambda$ have large confidence intervals that appropriately reflect their lack of precision. Furthermore, the overall trend in abundance is not affected by these estimates nearly as much as for river spawning LRS.

For river spawning LRS, the size composition data are less likely to be misleading about recruitment of new spawners than the seniority estimates for a few reasons. First, as discussed above, the recapture probabilities in the seniority analysis are low, which can lead to estimability problems in capture-recapture models. We suspect that the fish interpreted as new recruits to the spawning population in the models are rather just individuals, or groups of individuals, that previously have avoided capture by the monitoring program. We expect that such issues with interpretation will resolve over time as more of the population is captured and PIT-tagged. Second, the addition of a substantial number of new recruits to the spawning population should cause a reduction in the percentage of fish captured in a given year that were previously captured and tagged. The percentage of river spawning LRS that are recaptures has rarely declined from one year to the next, so any additions of new recruits must be relatively small. Finally, most fish in the populations are large adults and new recruits should be evident as a smaller mode in the size composition data. Smaller fish that could be considered new recruits have not made up a substantial part of the catch in any year in the last decade. Sampling with the same trammel nets in the past in Upper Klamath Lake (Janney and others, 2008), as well as in Clear Lake Reservoir, California, where recruitment of new spawners has occurred (Hewitt and Hayes, 2013), showed that the nets captured fish as small as $300 \mathrm{~mm}$ FL. Thus, trammel net selectivity cannot explain the lack of smaller fish in the recent catches in Upper Klamath Lake. If new recruits were contributing to the catches but were similar in size to the other, older adults, this would imply substantial changes in growth or maturity dynamics, or both (for example, reproduction shifted to an older age or larger body size). The most commonly observed response in stressed populations of fishes, including populations that have been substantially reduced in abundance, is a shift in maturity to smaller size and younger age (Trippel, 1995; Olsen and others, 2005). However, most such evidence comes from studies of populations that have been affected by fishing, circumstances that are not directly applicable to imperiled suckers in Upper Klamath Lake. Furthermore, other responses in terms of growth or maturity have been predicted and documented (Stearns and Koella, 1986; Trippel and Harvey, 1989; Reznick, 1990; Reznick and others, 1990). Without more direct evidence, we cannot be conclusive about the role of changing growth or maturity dynamics in our assessment of recruitment for river spawning LRS, but the role of any such change must still be reconciled with the other concerns discussed above. Overall, the weight of evidence currently favors little recruitment of new spawners and thus seniority estimates from capture-recapture models that are negatively biased in some years. 


\section{Acknowledgments}

We thank Mark Johnson, Amari Dolan-Caret, Todd Perry, Justin Miles, Courtney Fujishin, Mark Hereford, Zach Thoma, Josh Muswieck, and all members of past field crews for their dedication to the project and their assistance with data curation and management. We thank Toby Kock and Carl Ostberg for reviewing drafts of this report.

\section{Project Funding}

Funding was provided by the Bureau of Reclamation, U.S. Department of Interior. Funding was provided by the Bureau of Reclamation as part of its mission to manage, develop, and protect water and related resources in an environmentally and economically sound manner in the interest of the American public.

\section{References Cited}

Abadi, F., Botha, A., and Altwegg, R., 2013, Revisiting the effect of capture heterogeneity on survival estimates in capture-mark-recapture studies-Does it matter?: PLOS One, v. 8, p. 1-8 (e62636).

Anderson, D.R., Burnham, K.P., and White, G.C., 1994, AIC model selection in overdispersed capturerecapture data: Ecology, v. 75, p. 1,780-1,793.

Anthony, R.G., Forsman, E.D., Franklin, A.B., Anderson, D.R., Burnham, K.P., White, G.C., Schwarz, C.J., Nichols, J.D., Hines, J.E., Olson, G.S., Ackers, S.H., Andrews, L.S., Biswell, B.L., Carlson, P.C., Diller, L.V., Dugger, K.M., Fehring, K.E., Fleming, T.L., Gerhardt, R.P., Gremel, S.A., Gutiérrez, R.J., Happe, P.J., Herter, D.R., Higley, J.M., Horn, R.B., Irwin, L.L., Loschl, P.J., Reid, J.A., and Sovern, S.G., 2006, Status and trends in demography of northern spotted owls, 1985-2003: Wildlife Monographs, v. 163, 48 p.

Banish, N.P., Adams, B.J., Shively, R.S., Mazur, M.M., Beauchamp, D.A., and Wood, T.M., 2009, Distribution and habitat associations of radio-tagged adult Lost River suckers and shortnose suckers in Upper Klamath Lake, Oregon: Transactions of the American Fisheries Society, v. 138, p. 153-168. Baudisch, A., 2011, The pace and shape of aging: Methods in Ecology and Evolution, v. 2, p. 375-382. Bradbury, J.P., Colman, S.M., and Reynolds, R.L., 2004, The history of recent limnological changes and human impact on Upper Klamath Lake, Oregon: Journal of Paleolimnology, v. 31, p. 151-165.

Buckland, S.T., Burnham, K.P., and Augustin, N.H., 1997, Model selection-An integral part of inference: Biometrics, v. 53, p. 603-618.

Burdick, S.M., Hewitt, D.A., Rasmussen, J.E., Hayes, B.S., Janney, E.C., and Harris, A.C., 2015, Effects of lake surface elevation on shoreline-spawning Lost River Suckers: North American Journal of Fisheries Management, v. 35, p. 478-490.

Burnham, K.P., and Anderson, D.R., 2002, Model selection and multimodel inference-A practical information-theoretic approach (2d ed.): New York, Springer, 488 p.

Choquet, R., Lebreton, J.D., Gimenez, O., Reboulet, A.M., and Pradel, R., 2009, U-CARE-Utilities for performing goodness of fit tests and manipulating CApture-REcapture data: Ecography, v. 32, p. 1,071-1,074.

Cooch, E., and White, G., eds., 2013, Program MARK-A gentle introduction (12th ed.): Program Mark, accessed October 16, 2013, at http://www.phidot.org/software/mark/docs/book/.

Cooperman, M., and Markle, D.F., 2003, Rapid out-migration of Lost River and shortnose sucker larvae from in-river spawning beds to in-lake rearing grounds: Transactions of the American Fisheries Society, v. 132, p. 1,138-1,153. 
Cubaynes, S., Pradel, R., Choquet, R., Duchamp, C., Gaillard, J.-M., Lebreton, J.-D., Marboutin, E., Miquel, C., Reboulet, A.-M., Poillot, C., Taberlet, P., and Gimenez, O., 2010, Importance of accounting for detection heterogeneity when estimating abundance-The case of French wolves: Conservation Biology, v. 24, p. 621-626.

Dieterman, D.J., Frank, J., Painovich, N., and Staples, D.F., 2010, Lake sturgeon population status and demography in the Kettle River, Minnesota, 1992-2007: North American Journal of Fisheries Management, v. 30, p. 337-351.

Eilers, J.M., Kann, J., Cornett, J., Moser, K., and St. Amand, A., 2004, Paleolimnological evidence of change in a shallow, hypereutrophic lake-Upper Klamath Lake, Oregon, USA: Hydrobiologia, v. 520, p. 7-18.

Eldridge, D.B., Eldridge, S.L.C., Schenk, L.N., Tanner, D.Q., and Wood, T.M., 2012, Water-quality data from Upper Klamath and Agency Lakes, Oregon, 2009-10: U.S. Geological Survey Open-File Report 2012-1142, $32 \mathrm{p}$.

Eldridge, S.L.C., Wood, T.M., Echols, K.R., and Topping, B.R., 2013, Microcystins, nutrient dynamics, and other environmental factors during blooms of non-microcystin-producing Aphanizomenon flosaquae in Upper Klamath Lake, Oregon, 2009: Lake and Reservoir Management, v. 29, p. 68-81.

Finch, C.E., 2009, Update on slow aging and negligible senescence-A mini-review: Gerontology, v. 55, p. 307-313.

Fletcher, D., and Efford, M.G., 2009, Effect of senescence on estimation of survival probability when age is unknown, in Thomson, D.L., Cooch, E.G., and Conroy, M.J., eds., Modeling demographic processes in marked populations: New York, Springer, p. 1,037-1,053.

Fletcher, D., Lebreton, J.-D., Marescot, L., Schaub, M., Gimenez, O., Dawson, S., and Slooten, E., 2012, Bias in estimation of adult survival and asymptotic population growth rate caused by undetected capture heterogeneity: Methods in Ecology and Evolution, v. 3, p. 206-216.

Franklin, A.B., 2001, Exploring ecological relationships in survival and estimating rates of population change using Program MARK, in Field, R., Warren, R.J., Okarma, H., and Sievert, P.R., eds., Proceedings of the Second International Wildlife Management Congress: Bethesda, Maryland, The Wildlife Society, p. 350-356.

Hamilton, W.D., 1966, The moulding of senescence by natural selection: Journal of Theoretical Biology, v. 12, p. 12-45.

Hewitt, D.A., and Hayes, B.S., 2013, Monitoring of adult Lost River and shortnose suckers in Clear Lake Reservoir, California, 2008-2010: U.S. Geological Survey Open-File Report 2013-1301, 18 p.

[Also available at http://pubs.usgs.gov/of/2013/1301/.]

Hewitt, D.A., Hayes, B.S., Janney, E.C., Harris, A.C., Koller, J.P., and Johnson, M.A., 2011, Demographics and run timing of adult Lost River (Deltistes luxatus) and shortnose (Chasmistes brevirostris) suckers in Upper Klamath Lake, Oregon, 2009: U.S. Geological Survey Open-File Report 2011-1088, 38 p. [Also available at http://pubs.usgs.gov/of/2011/1088/.]

Hewitt, D.A., Janney, E.C., Hayes, B.S., and Harris, A.C., 2012, Demographics and run timing of adult Lost River (Deltistes luxatus) and shortnose (Chasmistes brevirostris) suckers in Upper Klamath Lake, Oregon, 2011: U.S. Geological Survey Open-File Report 2012-1193, 42 p. [Also available at http://pubs.usgs.gov/of/2012/1193/.]

Hewitt, D.A., Janney, E.C., Hayes, B.S., and Harris, A.C., 2014, Demographics and run timing of adult Lost River (Deltistes luxatus) and shortnose (Chasmistes brevirostris) suckers in Upper Klamath Lake, Oregon, 2012: U.S. Geological Survey Open-File Report 2014-1186, 44 p. [Also available at http://pubs.usgs.gov/of/2014/1186/.]

Hewitt, D.A., Janney, E.C., Hayes, B.S., and Harris, A.C., 2015, Status and trends of adult Lost River (Deltistes luxatus) and shortnose (Chasmistes brevirostris) sucker populations in Upper Klamath 
Lake, Oregon, 2014: U.S. Geological Survey Open-File Report 2015-1189, 36 p., http://dx.doi.org/10.3133/ofr20151189.

Hewitt, D.A., Janney, E.C., Hayes, B.S., and Shively, R.S., 2010, Improving inferences from fisheries capture-recapture studies through remote detection of PIT tags: Fisheries, v. 35, p. 217-231.

Hightower, J.E., and Gilbert, R.J., 1984, Using the Jolly-Seber model to estimate population size, mortality, and recruitment for a reservoir fish population: Transactions of the American Fisheries Society, v. 113, p. 633-641.

Hines, J.E., and Nichols, J.D., 2002, Investigations of potential bias in the estimation of $\lambda$ using Pradel's (1996) model for capture-recapture data: Journal of Applied Statistics, v. 29, p. 573-587.

Hoilman, G.R., Lindenberg, M.K., and Wood, T.M., 2008, Water quality conditions in Upper Klamath and Agency Lakes, Oregon, 2005: U.S. Geological Survey Scientific Investigations Report 20085026, $44 \mathrm{p}$.

Holzmann, H., Munk, A., and Zucchini, W., 2006, On identifiability in capture-recapture models: Biometrics, v. 62, p. 934-939.

Janney, E.C., Barry, P.M., Hayes, B.S., Shively, R.S., and Scott, A., 2006, Demographic analysis of adult Lost River suckers and shortnose suckers in Upper Klamath Lake and its tributaries, Oregon: Report to the Klamath Area Office of the Bureau of Reclamation, U.S. Geological Survey, Klamath Falls Field Station, Oregon, 42 p.

Janney, E.C., Hayes, B.S., Hewitt, D.A., Barry, P.M., Scott, A., Koller, J., Johnson, M., and Blackwood, G., 2009, Demographics and 2008 run timing of adult Lost River (Deltistes luxatus) and shortnose (Chasmistes brevirostris) suckers in Upper Klamath Lake, Oregon, 2008: U.S. Geological Survey Open-File Report 2009-1183, 32 p. [Also available at http://pubs.usgs.gov/of/2009/1183/.]

Janney, E.C., Shively, R.S., Hayes, B.S., Barry, P.M., and Perkins, D., 2008, Demographic analysis of Lost River sucker and shortnose sucker populations in Upper Klamath Lake, Oregon: Transactions of the American Fisheries Society, v. 137, p. 1,812-1,825.

Jones, O.R., Scheuerlein, A., Salguero-Gomez, R., Camarda, C.G., Schaible, R., Casper, B.B., Dahlgren, J.P., Ehrlen, J., Garcia, M.B., Menges, E.S., Quintana-Ascencio, P.F., Caswell, H., Baudisch, A., and Vaupel, J.W., 2014, Diversity of ageing across the tree of life: Nature, v. 505, p. 169-173.

Kann, J., and Smith, V.H., 1999, Estimating the probability of exceeding elevated pH values critical to fish populations in a hypereutrophic lake: Canadian Journal of Fisheries and Aquatic Sciences, v. 56, p. 2,262-2,270.

Laake, J., 2011, RMark—R code for MARK analysis, version 2.0.1: RMark Package, accessed May 16, 2011, at http://www.phidot.org/software/mark/rmark/.

Laake, J., and Rexstad, E., 2013, RMark-An alternative approach to building linear models in MARK, Appendix C in Cooch, E., and White, G., eds., Program MARK-A gentle introduction (12th ed.): RMark Package, accessed October 16, 2013, at http://www.phidot.org/software/mark/docs/book/.

Lebreton, J.-D., Burnham, K.P., Clobert, J., and Anderson, D.R., 1992, Modeling survival and testing biological hypotheses using marked animals - A unified approach with case studies: Ecological Monographs, v. 62, p. 67-118.

Lindenberg, M.K., Hoilman, G., and Wood, T.M., 2009, Water quality conditions in Upper Klamath and Agency Lakes, Oregon, 2006: U.S. Geological Survey Scientific Investigations Report 20085201, 54 p. [Also available at http://pubs.usgs.gov/sir/2008/5201/.]

Link, W.A., 2003, Nonidentifiability of population size from capture-recapture data with heterogeneous detection probabilities: Biometrics, v. 59, p. 1,123-1,130. 
Marescot, L., Pradel, R., Duchamp, C., Cubaynes, S., Marboutin, E., Choquet, R., Miquel, C., and Gimenez, O., 2011, Capture-recapture population growth rate as a robust tool against detection heterogeneity for population management: Ecological Applications, v. 21, p. 2,898-2,907.

Markle, D.F., and Cooperman, M.S., 2002, Relationships between Lost River and shortnose sucker biology and management of Upper Klamath Lake, in Braunworth, W.S., Jr., Welch, T., and Hathaway, R., eds., Water allocation in the Klamath Reclamation Project, 2001: Corvallis, Oregon State University Extension Service, Special Report 1037, p. 93-117.

McNamara, J.M., Houston, A.I., Barta, Z., Scheuerlein, A., and Fromhage, L., 2009, Deterioration, death and the evolution of reproductive restraint in late life: Proceedings of the Royal Society B, $v$. 276, p. 4,061-4,066.

Morgan, B.J.T., and Ridout, M.S., 2009, Estimating N-A robust approach to capture heterogeneity, in Thomson, D.L., Cooch, E.G., and Conroy, M.J., eds., Modeling demographic processes in marked populations: New York, Springer, p. 1,069-1,080.

Moyle, P.B., 2002, Inland fishes of California: Berkeley, University of California Press, 502 p.

National Research Council, 2004, Endangered and threatened fishes in the Klamath River Basin-Causes of decline and strategies for recovery: Washington, D.C., The National Academies Press, 397 p.

Nichols, J.D., 2005, Modern open-population capture-recapture models, in Amstrup, S.C., McDonald, T.L., and Manly, B.F.J., eds., Handbook of capture-recapture analysis: Princeton, New Jersey, Princeton University Press, p. 88-123.

Nichols, J.D., and Hines, J.E., 2002, Approaches for the direct estimation of $\lambda$, and demographic contributions to $\lambda$, using capture-recapture data: Journal of Applied Statistics, v. 29, p. 539-568.

Nichols, J.D., Hines, J.E., Lebreton, J.-D., and Pradel, R., 2000, Estimation of contributions to population growth-A reverse-time capture-recapture approach: Ecology, v. 81, p. 3,362-3,376.

Olsen, E.M., Lilly, G.R., Heino, M., Morgan, M.J., Brattey, J., and Dieckmann, U., 2005, Assessing changes in age and size at maturation in collapsing populations of Atlantic cod (Gadus morhua): Canadian Journal of Fisheries and Aquatic Sciences, v. 62, p. 811-823.

Otis, D.L., Burnham, K.P., White, G.C., and Anderson, D.R., 1978, Statistical inference from capture data on closed animal populations: Wildlife Monographs, v. 62, 135 p.

Perkins, D.L., Kann, J., and Scoppettone, G.G., 2000, The role of poor water quality and fish kills in the decline of endangered Lost River and shortnose suckers in Upper Klamath Lake: U.S. Geological Survey final report to the Bureau of Reclamation, Contract 4-AA-29-12160, Klamath Falls, Oregon, $39 \mathrm{p}$.

Peron, G., Crochet, P.-A., Choquet, R., Pradel, R., Lebreton, J.-D., and Gimenez, O., 2010, Capturerecapture models with heterogeneity to study survival senescence in the wild: Oikos, v. 119, p. 524532.

Pine, W.E., Allen, M.S., and Dreitz, V.J., 2001, Population viability of the Gulf of Mexico SturgeonInferences from capture-recapture and age-structured models: Transactions of the American Fisheries Society, v. 130, p. 1,164-1,174.

Pine, W.E., Pollock, K.H., Hightower, J.E., Kwak, T.J., and Rice, J.A., 2003, A review of tagging methods for estimating fish population size and components of mortality: Fisheries, v. 28, no. 10, p. $10-23$.

Pledger, S., Pollock, K.H., and Norris, J.L., 2010, Open capture-recapture models with heterogeneityII-Jolly-Seber model: Biometrics, v. 66, p. 883-890.

Pollock, K.H., Nichols, J.D., Brownie, C., and Hines, J.E., 1990, Statistical inference for capturerecapture experiments: Wildlife Monographs, no. 107, 97 p.

Pollock, K.H., Yoshizaki, J., Fabrizio, M.C., and Schram, S.T., 2007, Factors affecting survival rates of a recovering lake trout population estimated by mark-recapture in Lake Superior, 1969-1996: Transactions of the American Fisheries Society, v. 136, p. 185-194. 
Pradel, R., 1996, Utilization of capture-mark-recapture for the study of recruitment and population growth rate: Biometrics, v. 52, p. 703-709.

Pradel, R., Choquet, R., Lima, M.A., Merritt, J., and Crespin, L., 2010, Estimating population growth rate from capture-recapture data in presence of capture heterogeneity: Journal of Agricultural, Biological, and Environmental Statistics, v. 15, p. 248-258.

R Development Core Team, 2011, R-A language and environment for statistical computing: Vienna, Austria, R Foundation for Statistical Computing, accessed May 16, 2011, at http://www.Rproject.org/.

Reiser, D.W., Loftus, M., Chapin, D., Jeanes, E., and Oliver, K., 2001, Effects of water quality and lake level on the biology and habitat of selected fish species in Upper Klamath Lake: Portland, Oregon, R2 Resource Consultants, Inc., report to the Bureau of Indian Affairs, $147 \mathrm{p}$.

Reznick, D.N., 1990, Plasticity in age and size at maturity in male guppies (Poecilia reticulata) —An experimental evaluation of alternative models of development: Journal of Evolutionary Biology, v. 3, p. 185-203.

Reznick, D.A., Bryga, H., and Endler, J.A., 1990, Experimentally induced life-history evolution in a natural population: Nature, v. 346, p. 357-359.

Scoppettone, G.G., and Vinyard, G., 1991, Life history and management of four endangered lacustrine suckers, in Minckley, W.L., and Deacon, J.E., eds., Battle against extinction-Native fish management in the American West: Tucson, The University of Arizona Press, p. 359-377.

Stearns, S.C., and Koella, J.C., 1986, The evolution of phenotypic plasticity in life-history traitsPredictions of reaction norms for age and size at maturity: Evolution, v. 40, p. 893-913.

Terwilliger, M.R., Reece, T., and Markle, D.F., 2010, Historic and recent age structure and growth of endangered Lost River and shortnose suckers in Upper Klamath Lake, Oregon: Environmental Biology of Fishes, v. 89, p. 239-252.

Tobin, J.H., 1994, Construction and performance of a portable resistance board weir for counting migrating adult salmon in rivers: U.S. Fish and Wildlife Service, Kenai, Alaska, Alaska Fisheries Technical Report Number 22.

Trippel, E.A., 1995, Age at maturity as a stress indicator in fisheries: BioScience, v. 45, p. 759-771. Trippel, E.A., and Harvey, H.H., 1989, Missing opportunities to reproduce-An energy dependent or fecundity gaining strategy in white sucker (Catostomus commersoni)?: Canadian Journal of Zoology, v. 67 , p. $2,180-2,188$.

U.S. Fish and Wildlife Service, 1988, Endangered and threatened wildlife and plants-Determination of endangered status for the shortnose sucker and Lost River sucker: Federal Register, 53(137), p. 27,130-27,134.

U.S. Fish and Wildlife Service, 1993, Lost River (Deltistes luxatus) and shortnose (Chasmistes brevirostris) sucker recovery plan: U.S. Fish and Wildlife Service, Portland, Oregon, 108 p.

U.S. Fish and Wildlife Service, 2012, Revised recovery plan for the Lost River sucker (Deltistes luxatus) and shortnose sucker (Chasmistes brevirostris): U.S. Fish and Wildlife Service, Pacific Southwest Region, Sacramento, California, xviii +122 p.

Vaupel, J.W., Baudisch, A., Dolling, M., Roach, D.A., and Gampe, J., 2004, The case for negative senescence: Theoretical Population Biology, v. 65, p. 339-351. 
Wensink, M.J., Wrycza, T.F., and Baudisch, A., 2014, No senescence despite declining selection pressure-Hamilton's result in broader perspective: Journal of Theoretical Biology, v. 347, p. 176181.

White, G.C., and Burnham, K.P., 1999, Program MARK - Survival rate estimation from populations of marked animals: Bird Study, v. 46 (Supplement), p. S120-S139.

Williams, B.K., Nichols, J.D., and Conroy, M.J., 2002, Analysis and management of animal populations: New York, Academic Press, 817 p.

Williams, P.D., Day, T., Fletcher, Q., and Rowe, L., 2006, The shaping of senescence in the wild:

Trends in Ecology and Evolution, v. 21, p. 458-463.

Wood, T.M., Hoilman, G.R., and Lindenberg, M.K., 2006, Water-quality conditions in Upper Klamath Lake, Oregon, 2002-04: U.S. Geological Survey Scientific Investigations Report 2006-5209, 52 p. [Also available at http://pubs.usgs.gov/sir/2006/5209/.]

Zehfuss, K.P., Hightower, J.E., and Pollock, K.H., 1999, Abundance of Gulf Sturgeon in the Apalachicola River, Florida: Transactions of the American Fisheries Society, v. 128, p. 130-143. 
Publishing support provided by the U.S. Geological Survey

Science Publishing Network, Tacoma Publishing Service Center

For more information concerning the research in this report, contact the Director, Western Fisheries Research Center

U.S. Geological Survey

6505 NE 65th Street

Seattle, Washington 98115

http://wfrc.usgs.gov/ 
